\title{
A FÜRJ Coturnix coturnix (LINNAEUS, 1758) ÉLŐHELYVÁLASZTÁSÁNAK VIZSGÁLATA AGRÁRKÖRNYEZETBEN
}

\author{
Németh Tamás Márton ${ }^{1}$, Kelemen Petra ${ }^{1}$, Csiszár Ágnes ${ }^{2}$, Kovács Gyula ${ }^{1}$, Faragó Sándor ${ }^{1}$ \\ \& Winkler Dániel ${ }^{1}$
}

\author{
${ }^{1}$ Soproni Egyetem, Vadgazdálkodási és Gerinces Állattani Intézet \\ University of Sopron, Institute of Wildlife Management and Vertebrate Zoology, \\ ${ }^{2}$ Soproni Egyetem, Növénytani és Természetvédelmi Intézet \\ University of Sopron, Department of Botany and Nature Conservation \\ H-9400 Sopron, Bajcsy-Zs u. 4., Hungary; e-mail: tomanemeth@ gmail.com
}

\begin{abstract}
NÉmeth T.M., Kelemen P., Csiszár Á., KovÁcs Gy., FARAgó S. \& Winkler D. (2019): HABITAT SELECTION OF THE COMMON QUAIL (Coturnix coturnix) IN AGRICULTURAL ENVIRONMENT. Hungarian Small Game Bulletin 14: 141-163. http://dx.doi.org/10.17243/mavk.2019.141

The present study investigated the habitat selection of the Common Quail (Coturnix coturnix) in both intensively (LAJTA Project) and extensively managed (MOSON Project) agricultural environments in North-West Hungary. In order to assess the habitat preferences of the Common Quail, habitat composition around occupied plots were compared with unoccupied control plots. Multivariate methods (PCA, DFA and GLMs) were used to distinguish the main factors influencing the habitat selection and to model the presence of the Common Quail. To characterize the habitat, variables related to vegetation structure and diversity, food availability and landscape were quantified. Based on the results, high probability of Common Quail presence can be predicted in plots with higher herbaceous cover and more abundant arthropod communities. The network of ecotone habitats, particularly the proximity to woody habitats, also appeared to have significant importance during the breeding season.
\end{abstract}

KULCSZAVAK: fürj, táplálékkínálat, növényborítás, szegélyökotonok KEY WORDS: Common quail, food availability, plant cover, edge ecotones

\section{BEVEZETÉS}

Ahhoz, hogy a fajok élöhelyválasztását megértsük, fontos, hogy a habitat vagy élöhely kifejezést értelmezzük. Az egységes definíciót - az egyszerübbtől a bonyolultabbig - számos kutató próbálta megfogalmazni (pl. WHITTAKER et al. 1973, HALL et al. 1997, MORRIS 2003, KEARNEY 2006). A kifejezést általában egy adott faj vagy populáció fizikai környezetének leírására használják különböző térbeli léptékben nézve. Néha viszont a definíció magában foglalja a faj/populáció állandóságát vagy egyéni túlélési és reprodukciós képességét is (WHITTAKER et al. 1973, HALL et al. 1997).

A fajok élőhelyeinek tanulmányozásánál alapvető, hogy megismerjük az adott faj ökológiai igényeit, amplitúdóját, ami kifejezi a faj és környezete közötti kapcsolatot. A különböző fajok élőhelyének vizsgálatával foglalkozó terület viszonylag fiatal az ökológia tudományán belül. A témakör az 1970-es évek kezdetén vált egyre aktuálisabbá, ami egybeesett a fajok elterjedésének feltárására irányuló növekvő érdeklődéssel (GUISAN \& THUILLER 2005). MORRIS (2003) szerint a legtöbb vizsgálat célja az élőhelyválasztást befolyásoló különböző tényezők szerepének megértése, amelyek meghatározzák az egyedek térbeli eloszlását is. Ezen alkotóelemek közé tartozik például az elterjedés, a rendelkezésre álló táplálékforrások, a 
rendelkezésre álló hely (MORRIS \& DAVIDSON 2000), vagy akár a fajon belüli és fajok közötti interakciók (ROSENZWEIG 1981, MORRIS 1999). Gyakran előfordul az is, hogy a megfelelö élőhelyek korlátozottan állnak rendelkezésre az egyedek számára, így azok a kevésbé kedvező vagy rosszabb feltételekkel rendelkező élőhelyeket fogják elfoglalni (MORRIS 2003).

Tudva levő, hogy az európai mezei madárfajok populációjának csökkenéséért leginkább a mezőgazdasági művelés intenzifikációja a felelős (pl. CHAMBERLAIN \& FuLLER 2000, DoNALD et al. 2001, 2006, BÁLDI 2008, VoŘíšEK et al. 2010). Habár a csökkenés mértéke regionális szinten különbségeket mutat (WRETENBERG et al. 2006, BÁLDI \& FARAGÓ 2007, BÁLDI \& BATÁRY 2011, TRYJANOWSKI et al. 2011), ezért a folyamatok jobb megértése érdekében pontosabb populációvizsgálatokra van szükség.

A fürj (Coturnix coturnix L. 1758) az Európa területén előforduló fácánfélék (Phasanidae) legkisebb termetű és egyetlen olyan képviselője, amely hosszútávú vonulóként a Száhel öv füves területein telel (McGowAN et al. 1994). A nagy kiterjedésű nyílt, fa és cserje nélküli élőhelyeket kedveli (GLUTZ VON BLOTZHEIM et al. 1973), így feltehetőleg a füves puszták, illetve a gyérebb állományú erdős puszták madara volt (CRAMP 1980). Válaszul eredeti élőhelyei megfogyatkozására és átalakulására, sikerült alkalmazkodnia a különböző mezőgazdasági kultúrákhoz (CRAMP 1980). Ezzel a fürj az agrártájak jellegzetes madarává vált (UDVARDY 1941, GEORGE 1990, GUYOMARC'H et al. 1998).

A fürj az 1900-as évek elejéig általánosan elterjedt volt Európa-szerte. Állománycsökkenésére már a 19. század végén felfigyeltek (GLUTZ VON BLOTZHEIM et al. 1973). Az 1980-as években újabb csökkenést észleltek Nyugat-Európa legtöbb országában (PERENNOU 2009), amely csökkenő trend jellemzi még mindig a faj állományát az egyes európai országokban (BIRDLIFE INTERNATIONAL 2018). Állománya hazai viszonylatban is csökkenés mutat, országos és régiós szinten is (SZÉP et al. 2012, NÉMETH et al. 2014, MME 2018). A fészkelő populáció nagysága 74000 és 90000 pár közöttire tehető (HADARICS \& ZALAI 2008, BIRDLIFE INTERNATIONAL 2018).

Fürjre vonatkozó vizsgálatokat - amelyek az élőhelyhasználatával, mozgásával, a japán fürjjel (Coturnix japonica) való hibridizációval vagy a populáció eloszlásával voltak összefüggésben - elsősorban Nyugat-Európában (Franciaország, Németország, Spanyolország) végeztek (pl. SAINT-JALME \& GUYOMARC'H 1989, GEORGE 1990, 1996, GuYOMARC'H 2003, PuigCERVER et al. 1999, 2007). Magyarországon a fürj kevésbé tanulmányozott faj. A hazai szakirodalomban leginkább faunisztikai tanulmányokkal találkozhatunk (pl. SzÜTS 1898, BARTHOS 1917, KÜLLEY 1924, BÁN \& IGMÁNDY 1939, RAPOS 1957, DEBRECENI et al. 1990, KOVÁCS 2005, FARAGÓ 2012b), a faj ökológiájának kutatásávalkevesen foglalkoztak (lásd KEVE et al. 1953),

Munkánk célja az volt, hogy feltárja azokat az ökológiai tényezőket, amelyek a fürj számára az élőhelyválasztásban kulcsfontosságúak a művelés alatt álló agrárélőhelyeken. A vizsgálat során az alábbi kérdésekre kerestünk válaszokat: (i) melyek azok az élőhelyet jellemző, a növényzet struktúrájára, az ízeltlábú táplálékkínálatra és a tájszerkezetre vonatkozó változók, amelyek a fürj jelenlétét és habitatválasztását leginkább meghatározzák, befolyásolják; illetve (ii) mutatkoznak-e eltérések a fürj habitatválasztását illetően intenzív és extenzív agrárkörnyezetben?

\section{ANYAG ÉS MÓDSZER}

\subsection{VIZSGÁLATI TERÜLETEK A MOSONI-SÍKON}

A tájföldrajzi besorolás szerint a Kisalföld földrajzi nagytájban található Mosoni-sík határát keleten a Mosoni-Duna, északon és nyugaton az országhatár, míg délen az Újrónafö- 
Lébény-Abda vonal képezi (DÖVÉNYI 2010). Az erdészeti tájbeosztás a területet már nem a Hansághoz, hanem a Szigetköz-Rábaköz tájba és azon belül a Mosoni síkság tájrészletbe sorolja be (HALÁSZ 2006). A kistáj egész területe magas ártéri fekvésü, hordalékkúpon kialakult síkság. A vidéket a folyóvizek medrei gazdagon tagolják. Alapvetően mérsékelten hüvös, de K-en mérsékelten meleg, száraz éghajlat jellemzi.

A Mosoni-sík egykori természetes növényzete gyökeresen átalakult, elszegényedett, a természetszerü vegetációs egységek térfoglalása minimális. A táj mai képét a szántóföldi müvelés határozza meg, az erős fragamentációhoz a sok közlekedési létesítmény is hozzájárul. A nagytáblás, intenzív mezőgazdálkodás jellemzi a tájat, viszont a mezővédő erdősávok aránya kedvező. Főleg kalászosokat, kukoricát, pillangósokat és repcét termesztenek (FARAGÓ 2012b). A Mosoni-sík egykor számos száraz gyeppel és nedves réttel rendelkezett. Ezen gyepes élőhelyek ma már kis kiterjedésűek, általában keskenyek és az állandósuló szegélyhatás, fizikai károsodások, vegyszerbemosódás és adventív fafajok terjedése miatt erősen leromlottak vagy el is tüntek.

\subsubsection{LAJTA Project}

A LAJTA Project létrejöttének alapvető célja a mezei élőhelyeken élő vadfajok (vadászható és védett fajok) és környezetüknek hosszú távú vizsgálata, valamint az ökológiai szemléletü apróvadgazdálkodás hazai elindítása volt, amely a tenyésztés megtartása mellett az élőhelyek állapotának javításával próbálja a fenntarthatóság feltételeit megteremteni és azt hosszú távon müködtetni.

A projektterület közigazgatásilag Mosonszolnok község (40,6\%) és Jánossomorja város $(59,4 \%)$ határában helyezkedik el (1. ábra). A projekt feladata alapításától kezdődően a tartamosság (,„long-term”) biztosítása volt, tehát nem csak egy adott állapotot, de folyamatokat is rögzíteni kíván, így lehetőséget biztosít az ok-okozati összefüggések, a rendszerelemek kapcsolatainak, müködési mechanizmusainak tisztázására, a beavatkozások hatáselemzésére (FARAGÓ 2012b).

Az erdőssztyep vegetáció az évezredek folyamán elszegényedett, zömében elvesztette az erdőfoltokat a Mosoni-síkon, különösen a LAJTA Project térségében, sőt a természetes gyepek is kis kiterjedésben, erősen degradálva, reliktum jelleggel vannak jelen. A földhasználatra itt is az intenzív nagyüzemi növénytermesztés (átlag 45-50 ha-os táblanagyság) és a szántók túlsúlya jellemző. A terület főbb élőhelytípusai közül a vizsgálat szempontjából a gyepek, ugarok és szántók érdekesek. A vizsgált területen található gyepsávok nem hasznosított területek, nagyságuk 1 ha, amelyek mesterségesen létrehozott, vetett területek (FARAGÓ 2012c). A szántóterületek nagysága 2810 ha, a termesztett növények területi aránya a vizsgálati időszakokban változó volt. Az adott évre vetésterv készül, amit a projekt munkatársai tényleges havi vetésterület térképen pontosítanak minden hónap 15 . napján (FARAGÓ 2012c). A vegyszermentes táblaszegélyek hossza kb. $15 \mathrm{~km}$, a vadföldsávoké kb. $25 \mathrm{~km}$. Az erdészetileg üzemtervezett erdősávok és erdők képezik kiterjedésben (110 ha) és arányban $(3,5 \%)$ is a legfontosabb fás jellegü élőhelytípust (FARAGÓ 2012a). A LAJTA Project területén meghatározó jelentőségű a meszes, száraz talajokra jellemző, uralkodó szegetális gyomtársulás, a gomborka-pipitér társulás (Camelino microcarpae-Anthemidetum austriacae) (KIRÁLY \& KIRÁLY 2014).

\subsubsection{A MOSON Project}

Az 1992-ben indított élőhelyvédelmi program különösen a túzok- és fogolypopulációk védelmét és erősítését tüzte ki célként. A LAJTA Project-hez hasonlóan itt is alapvető célként 
szerepelt az élőhelyek állapotának javítása és a fenntarthatóság feltételeinek megteremtése hosszú távon.

A mintegy 880 ha kiterjedésü MOSON Project területe Hegyeshalom és Rajka települések között helyezkedik el (1. ábra). A területen régóta intenzív mezőgazdasági tevékenység folyt, valamint a külszíni kavicsbányák terjedése miatt az erdősztyep vegetáció itt is elszegényedett, a természetes gyepek is kis kiterjedésben, erősen degradálva vannak csak jelen. A szántókon a legnagyobb arányban termesztett növény az őszi búza és viszonylag nagy területen folyik a repce termesztése is. A túzok védelme szempontjából bevezetésre került az ún. vándorsávos mủvelés, amelynek lényege, hogy az ugar és az extenzíven müvelt területek váltása 1-5 éves különbséggel történik meg, ezenkívül nagyszámban megtalálhatóak az ún. túzokföldek is, amelyek a Mosoni-síkra jellemzö, parlag jellegü területek (FARAGÓ \& KALMÁR 2006). A túzok szaporodási időszakában továbbá mellőznek minden mezőgazdasági munkálatot a táblákban fészkelő madarak nyugalmának biztosítása érdekében (FARAGÓ \& KALMÁR 2006). Ahogy a LAJTA Project területén, itt is az erdősávok képezik kiterjedésben (kb. 30 ha) és arányban $(3,4 \%)$ is a legfontosabb fás jellegü élőhelytípust.

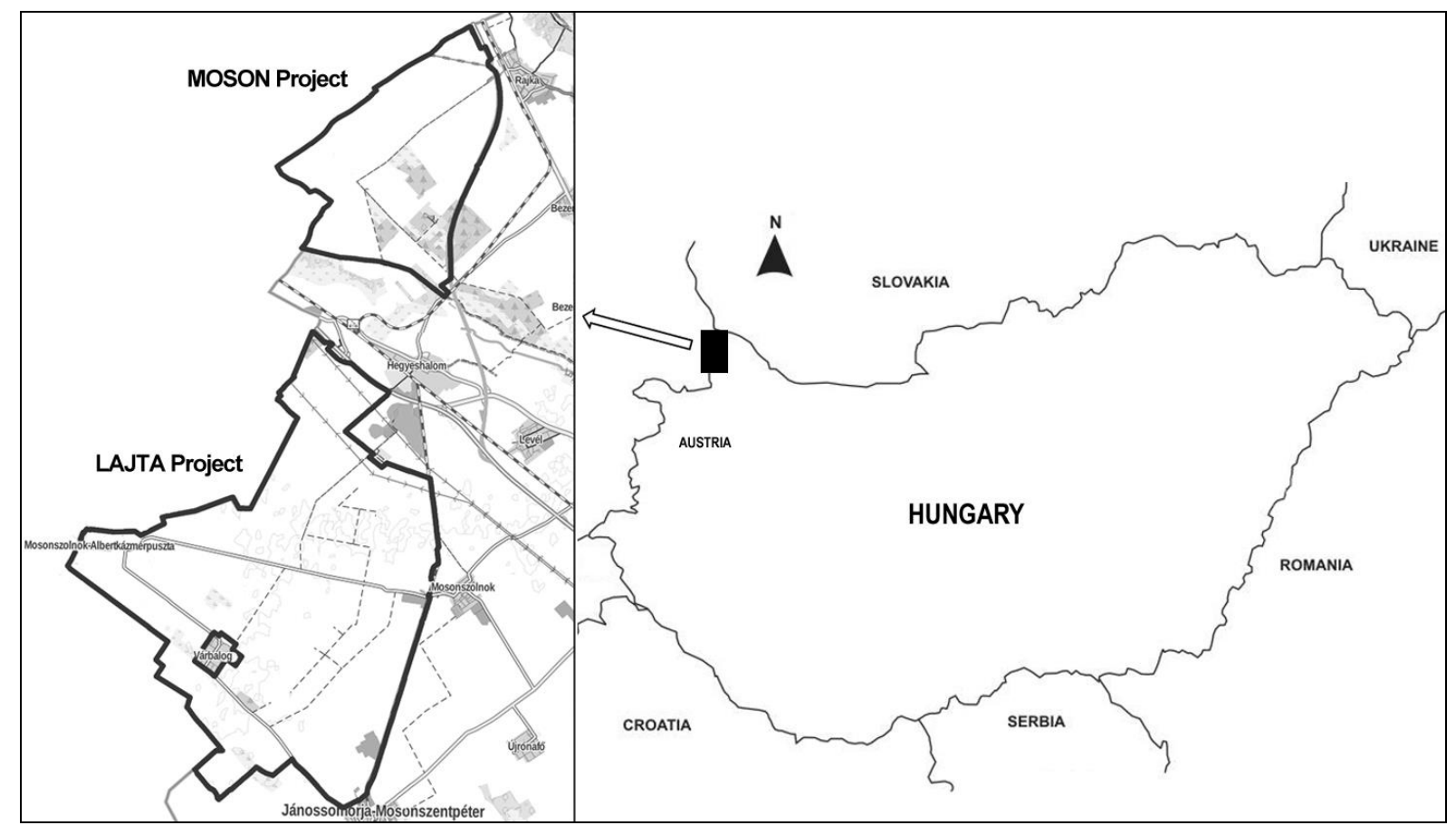

1. ábra: A vizsgálati terület (LAJTA project)

Figure 1. Map of the study area (LAJTA Project)

\subsection{TEREPI FELMÉRÉSI MÓDSZEREK}

\subsubsection{A fürj territóriumok felmérése}

A vizsgálat során a RODRÍGUEZ-TEIJEIRO et al. (2010) által javasolt, több országban (Spanyolország, Portugália, Franciaország, Marokkó) már eredményesen alkalmazott monitoring módszert vettük alapul. Megfelelő időjárási körülmények mellett (esőmentes, szélcsendes) havonta egy alkalommal, a kora reggeli órákban minden egyes megfigyelési pontnál 1,5 perces hallgatózás után egy rövid idejü (20-25 sec.) tojó hívóhang lejátszására került sor. Ennek oka, hogy az adott helyszínen az inaktív hímeket (ún. "silent males", de akár 
nevezhetjük szubdomináns kakasoknak) is hangadásra ösztönözzük. Minden pont egymástól min. 500 méterre volt, a dupla számolás elkerülése érdekében. Az éneklő kakasok helyét az adott kakastól 15-20 m távolságra megállva GPS készüléken bemértük. A felmérés 2014-ben a teljes költési időszakot felölelte (április második felétől augusztus közepéig).

\subsubsection{Az élőhelyi jellemzők felmérése}

A fürjek által kiválasztott élőhelyek vizsgálatához kétféle léptéket alkalmaztunk. A szakirodalmi adatok alapján (GUYOMARC'H et al. 1998a, PERENNOU 2009) egy szükebb léptékü, 75 m sugarú körben lehatárolt területet ( 1,5 ha) - a továbbiakban territórium lépték - vizsgáltunk. Ezen kívül a tájléptékü elemzéshez egy nagyobb, 500 m sugarú körrel ( 79 ha) lehatárolt területet is bevontunk a vizsgálatokba. Az elemzésekhez a LAJTA Project területén előzetesen felmért, foglalt "territóriumok" közül összesen 18 került kiválasztásra, valamint a habitatválasztást meghatározó fontosabb paraméterek feltárására további 18 , nem foglalt, kontroll pontnak és körzetének felvételezése is megtörtént. Mivel az így elemzésbe vont pontok kizárólag az intenzív agrárkörnyezetre reprezentatívak, további 18 territórium került kiválasztásra az extenzív gazdálkodással jellemezhető MOSON Project területén, a faj élőhelyválasztásának árnyaltabb és általánosabb érvényü értékeléséhez. A MOSON Project területének homogénebb élőhelyszerkezete és a fürj relatíve magasabb denzitása miatt kontroll pontok kijelölése itt nem volt lehetséges.

A territóriumok kiválasztásakor mindkét projekt területén belül fontos volt, hogy egymástól legalább $500 \mathrm{~m}$ távolságban legyenek. A kontroll pontok kitűzése a „Hawth's Analysis Tools" (BEYER 2004) alkalmazással történt, úgy, hogy a faj számára potenciális növényi kultúrákban válasszon ki helyszíneket (kizárva ezzel az egyéb alkalmatlan helyszíneket, pl. út, tó, lakótelek). A körök középpontja ( $\mathrm{r}=75 \mathrm{~m}$ és $\mathrm{r}=500 \mathrm{~m})$ a territóriumok esetében az éneklő egyed helye (korábbi terepi felmérés), a kontroll helyeknél a generált pontok voltak. A tájléptékü $(\mathrm{r}=500 \mathrm{~m})$ kiértékelésbe vont jellemzők a következők voltak: fás ökotonok hossza (Wood_Lgth), gyepes táblaszegélyek hossza (Margin_Lgth), minimum távolság a fás ökotontól (Wood_Dist), minimum távolság a gyepes táblaszegélytől (Margin_Dist), valamint az utak hossza (Road_Lgth). A fás ökotonok hossza (Wood_Lgth) a tájléptékü körben $(\mathrm{r}=500 \mathrm{~m})$ lemért erdősávokat, fasorokat és/vagy bokorsávokat jelentette. A gyepes táblaszegélyek hosszát (Margin_Lgth) úgy határoztuk meg, hogy az nem tartalmazta a fás ökotonok és táblaszegély közötti lágyszárú vegetációs élőhely hosszát. A fás ökotonoktól és gyepes táblaszegélyektől vett minimum távolság (Wood_Dist és Margin_Dist) a kör középpontjától mért legközelebbi szegélyélöhely távolsága. Āz utak hossza (Road_Lgth) a körön belül található, földes, kavicsos és aszfalt utak hosszát jelenti.

\subsubsection{Cönológiai felmérések}

A fürjek által kedvelt helyszíneken és a kontroll kultúrákban 2014-ben botanikai felvételezés is történt. A felvételek során az adott kultúra lágyszárú/gyomflóráját vizsgáltuk. A felvételezés a BRAUN-BLANQUET módszert követte (JAKUCS \& PRÉCSÉNYI 1981). A borításértékek becslése a BALÁZS-UJVÁROSI skála alapján történt. A felmérést territórium léptékben végeztük el,

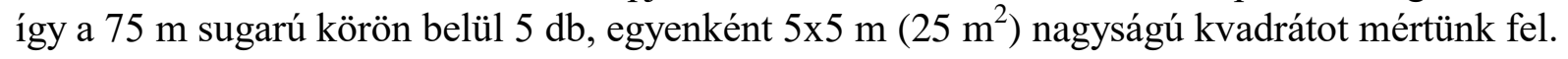

\subsubsection{A táplálékkínálat felmérése}

A talajfelszínen mozgó ízeltlábú (Arthropoda) táplálék élőhelyenkénti felmérése a nemzetközi gyakorlatban is elfogadott Barber-féle talajcsapdázással (BARBER 1931) történt, 3 
dl ürtartalmú és $8 \mathrm{~cm}$ szájátmérőjű mủanyagpoharakkal, amelyekben ölőfolyadékként 70\%os etilén-glikol oldatot használtunk. A poharak fölé alumíniumtetők kerültek, hogy a hüllő- és kisemlősfajok csapdába kerülését kiküszöböljük, továbbá, hogy védjük a csapda tartalmát a lehulló csapadéktól. A táplálékkínálatot a cönológiai felvételezéshez hasonlóan a territórium léptéken belül $(\mathrm{r}=75 \mathrm{~m})$ vizsgáltuk. A cönológiai felvételek kvadrátjain belül egy-egy talajcsapda $(\mathrm{n}=5)$ került kihelyezésre.

A begyüjtött minták válogatása és rendszertani besorolása után (1. táblázat), a minták tartalmát szárítószekrényben 24 órán keresztül $85-90^{\circ} \mathrm{C}$-on szárítottuk, ezután következett a száraz biomassza mérése.

1. táblázat: A táplálékkínálat-elemzés során azonosított ízeltlábú csoportok Table 1. Arthropod taxons identified

\begin{tabular}{lc}
\hline \multicolumn{1}{c}{ Ízeltlábú csoportok } & $\begin{array}{c}\text { Rendszertani kategória } \\
\text { Taxon level }\end{array}$ \\
\hline Arachnida - Pókszabásúak & Osztály - Class \\
Isopoda - Ászkarákok & Rend - Order \\
Diplopoda - Ikerszelvényesek & Osztály - Class \\
Chilopoda - Százlábúak & Osztály - Class \\
Collembola - Ugróvillások & Rend - Order \\
Blattodea - Csótányok & Rend - Order \\
Mantodea - Fogólábúak & Rend - Order \\
Orthoptera - Egyenesszárnyúak & Rend - Order \\
Dermaptera - Fülbemászók & Rend - Order \\
Heteroptera - Poloskák & Alrend - Suborder \\
Auchenorrhyncha - Kabócák & Alrend - Suborder \\
Coleoptera - Bogarak & Rend - Order \\
Lepidoptera - Lepkék & Rend - Order \\
Diptera - Kétszárnyúak & Rend - Order \\
Hymenoptera - Hártyásszárnyúak & Rend - Order \\
\hline
\end{tabular}

\subsection{A KIÉRTÉKELÉS MÓDSZEREI}

\subsubsection{Cönológiai felmérések kiértékelése}

A felmért kvadrátokban megállapítottuk az előforduló növényfajok számát, becsülve a borításukat. A lágyszárú diverzitást a SHANNON \& WEAVER (1949) által leírt formulával határoztuk meg:

$$
\begin{aligned}
& H^{\prime}=-\sum_{i=1}^{S} p_{i} \ln p_{i} \\
& \text { ahol: } \quad p_{i}=\frac{n_{i}}{N} \quad \text { és } \quad \sum_{i=1}^{S} p_{i}=1
\end{aligned}
$$

ahol: $\quad H^{\prime}:$ Shannon diverzitás

$S:$ összfajszám

$p_{i}$ : az i-edik faj relatív gyakorisága

$N$ : összes egyedszáma

$\mathrm{n}_{\mathrm{i}}$ : az i-edik faj egyedszáma 


\subsubsection{A táplálékkínálat értékelése}

A Barber-csapdák által gyüjtött ízeltlábú minták válogatása sztereomikroszkóp (20-30 szoros nagyítás) segítségével történt, majd taxononként meghatároztuk az egyedszámot. A taxon-diverzitást a SHANNON képlet segítségével határoztuk meg.

A növényzet és a táplálékkínálat diverzitását ezen kívül Rényi-féle diverzitási rendezéssel is elemeztük, amely módszer lehetővé teszi a közösségek diverzitásának összehasonlítását egy komplex diverzitási skála mentén (TÓTHMÉRÉSz 1997). Egy adott közösséget diverzebbnek nevezünk egy másiknál, ha profilja a másik fölött fut. Ha a profilok metszik egymást, akkor a diverzitás szempontjából a közösségek nem rangsorolhatók egyértelmüen.

\subsubsection{A habitatválasztás értékelése}

\subsubsection{Főkomponens-analízis (PCA)}

A LAJTA Project területén belül elhelyezkedő territóriumok és a kontrollpontok alapján a fürj élőhelypreferencia-összefüggéseinek feltárásához a felmért vegetáció, táplálékkínálat és egyéb élőhelyszerkezeti jellemzők értékeiből összeállított adatrendszerre főkomponens-analízist végeztünk. Ahhoz, hogy az élőhelyválasztást szélesebb spektrumon is értékelni tudjuk, egy következő lépésben a MOSON Project területén lévő territórium pontokat is bevontunk az elemzésekbe.

A főkomponens-elemzés (rövidítése PCA - Principal Component Analysis) egy olyan többváltozós statisztikai eljárás (adatredukciós módszer), amivel az adathalmaz dimenzióját csökkenteni lehet, de az adathalmaz karakterisztikája és lényeges információtartalma mégis megmarad (a jelen lévő varianciát a lehető legjobban megtartja), így a benne rejlő minták megtalálhatók és felismerhetők (JOLLIFFE 2002). A transzformáció a fökomponenseket a maximum variancia kritérium alapján határozza meg olyan módon, hogy a hozzájuk tartozó sajátértékek alapján sorba is rendezi. A Kaiser kritériumnak megfelelően az egynél nagyobb sajátértékü komponenseket vontuk be a további elemzésekbe. A főkomponens-elemzésbe bevont élőhelyváltozók adatrendszerét a 2. táblázat foglalja össze. A kiinduló élőhelyváltozók átlageltéréseit párosított t-próbával, HUTCHESON (1970) által módosított tpróbával (diverzitások), illetve egytényezős varianciaanalízissel (ANOVA) vizsgáltuk.

\section{2. táblázat: Az élőhelyet leíró jellemzők adatrendszere}

Table 2: Data system of the habitat structure variables

\begin{tabular}{ll}
\multicolumn{1}{c}{$\begin{array}{c}\text { Az adatrendszer komponensei } \\
\text { habitat variables }\end{array}$} & $\begin{array}{c}\text { Jelölés az elemzés során } \\
\text { abbreviations }\end{array}$ \\
\hline növényzet fajszáma - plant species richness & Plant_S \\
növényzet diverzitása (Shannon) - plant diversity (Shannon) & Plant_Div \\
növényzet borítása - plant cover & Plant_Cov \\
ízeltlábú egyedszám - arthropod number & Arth_Ind \\
ízeltlábú tömeg (száraz) - arthropod dry weight & Arth_W \\
ízeltlábú diverzitás (Shannon) - arthropod diversity & Arth_Div \\
fás ökotonok hossza - length of woody ecotones & Wood_Lgth \\
min. távolság fás ökotontól - min. distance from woody ecotones & Wood_Dist \\
gyepes táblaszegélyek hossza - length of grassy field margins & Margin_Lgth \\
min. távolság gyepes táblaszegélytől - min. distance from field margins & Margin_Dist \\
utak hossza - total length of roads & Road_Lgth \\
\hline
\end{tabular}


A létrejött új változók (főkomponensek) eltérését t-próbával (a foglalt és kontroll pontok között), illetve egytényezős varianciaanalízissel (ANOVA) elemeztük.

\subsubsection{2. Általánosított lineáris modell (GLMs)}

A főkomponens-analízis során kapott új változókat felhasználva általánosított lineáris modellt (GLMs) alkalmaztunk a fürj jelenlétének elörejelzésére. Mivel a fürj territórium foglaltságot bináris függő változónak tekintjük (jelenlét: 1, hiány: 0 ), a szignifikanciaszint megállapításához binomiális hibaszerkezetet (binomial error structure) és logit link funkciót használtunk (JANZEN \& STERN 1998). A magyarázó változókat (fökomponensek) a modellekbe elörehaladó lépésenkénti szelekcióval (forward stepwise) építettük be. A változók egyenként történő tesztelését követően a szignifikáns hatásúakat $(p<0.05)$ egy közös modellbe vontuk össze. A GLMs modell validitását Cohen-féle kappa statisztikával értékeltük, megadva a helyesen besorolt esetek arányát (COHEN 1960), a véletlen folytán előálló esetek valószínüségét figyelembe véve. LANDIS \& KоCH (1977) útmutatása alapján, ha a 0-0,4 közötti kappa érték gyenge, a 0,4-0,6 közötti érték közepes, a 0,6-0,8 közötti érték jó, 0,8-1 közötti érték pedig kiváló egybehangzóságot jelent.

\subsubsection{Diszkriminancia-analízis (DFA)}

A vizsgálati területen felmért fürjek habitatválasztásának finom eltéréseit az intenzív és extenzív agrárélőhelyeken diszkriminancia-analízis (DFA) segítségével elemeztük. A diszkriminancia-analízis célja, hogy alacsony mérési szintü függő változót magas mérési szintü független változók együttes figyelembevételével magyarázzon. A diszkriminanciaanalízis során a magyarázó változókból (habitatszerkezeti jellemzők) olyan diszkrimináló függvények jönnek létre, amelyek a legnagyobb különbségeket produkálják a függő változóban a definiált csoportok (fürj territóriumok és kontrollpontok) között.

A statisztikai elemzéseket a PAST 3.20 (HAMMER et al. 2001), a SAS v. 9.4 (SAS INSTITUTE 2013) és az SPSS v. 20.0 (IBM CORP. 2011) segítségével végeztük el.

\section{EREDMÉNYEK}

\subsection{A FÜRJ ÉLŐHELYVÁLASZTÁSÁT BEFOLYÁSOLÓ TÉNYEZŐK}

A fürj territóriumokban, illetve a kontrollpontokban felmért élőhelyszerkezeti, valamint a táplálékkínálatra vonatkozó változók értékeinek összehasonlítását az 3. táblázat mutatja be. A LAJTA Project területén felmért fürj territóriumok, valamint kontrollpontok vonatkozásában a növényzetet leíró változók szignifikáns eltérést mutattak, míg az ízeltlábú táplálékkínálat változói közül csak az egyedszámok között adódott szignifikáns különbség.

Az ízeltlábú táplálékkínálat eredményei azt mutatják, hogy a fürj számára potenciális zsákmányfajok közül mindkét mintaterületen a legnagyobb arányban a bogarak (Coleoptera), hártyásszárnyúak (Hymenoptera) és a pókok (Arachnida) közül kerültek ki, de a MOSON Project területén még az egyenesszárnyúak (Orthoptera) és az ászkarákok (Isopoda) is fontos szerepet játszhatnak a táplálkozásban. Az ugróvillások (Collembola) száma szintén magas volt, de elenyésző adat áll rendelkezésre európai szinten, hogy meghatározó összeteveője lenne a fürj táplálékának. A nagyobb méretű epedafikus fajok (pl. Orchesella spp., Seira spp.) fogyasztása azonban feltételezhető. 
3. táblázat: A fürj territóriumok, valamint kontroll mintaterületek élőhelykarakterisztikáinak összefoglaló áttekintése (átlag \pm SE (CV)); az átlagértékek összehasonlítása (t-próba ${ }^{a}$, módosított t-próbab (HUTCHESON); egytényezős ANOVA). $* \mathrm{p}<0,1 ; * * \mathrm{p}<0,05 ; * * * \mathrm{p}<0,01 ; \mathrm{ns}-$ nem szignifikáns

Table 3: Habitat characteristics (mean $\pm S E(C V)$ ) in the Common quail territories and control plots; comparison of men values ( $t$-test $t^{a}$; modified $t$-test ${ }^{b}$ (HUTCHESON); one-way ANOVA). ${ }^{*} p<0.1$;

$* * p<0.05 ; * * * p<0.01 ; n s-$ non significant

\begin{tabular}{lccccc}
\hline & $\begin{array}{c}\text { LAJTA Project } \\
\text { territórium }^{1,2}\end{array}$ & $\begin{array}{c}\text { LAJTA Project } \\
\text { kontroll }^{1,2}\end{array}$ & MOSON Project $^{2}$ & $\begin{array}{c}{ }^{1} \text { t-próba } \\
(\mathrm{t})\end{array}$ & $\begin{array}{c}{ }^{2} \text { ANOVA } \\
(\mathrm{F})\end{array}$ \\
\hline Plant_S & $25,1 \pm 1,29(16,3)$ & $19,4 \pm 0,72(10,8)$ & $33,9 \pm 1,23(11,5)$ & $2,698^{\mathrm{a} * *}$ & $34,59^{* * *}$ \\
Plant_Div & $2,14 \pm 0,07(10,8)$ & $1,91 \pm 0,08(12,5)$ & $2,46 \pm 0,09(11,2)$ & $2,162^{\mathrm{b} * *}$ & - \\
Plant_Cov & $41,0 \pm 8,07(62,2)$ & $25,4 \pm 1,52(18,9)$ & $94,3 \pm 1,68(5,6)$ & $2,496^{\mathrm{a} * *}$ & $55,80^{* * *}$ \\
Arth_Ind & $1624,8 \pm 215,1(41,9)$ & $1083,6 \pm 173,0(50,5)$ & $1733,7 \pm 244,2(44,5)$ & $2,178^{\mathrm{a} * *}$ & $2,68^{*}$ \\
Arth_W & $32,1 \pm 5,44(53,5)$ & $25,1 \pm 7,7(33,2)$ & $50,6 \pm 6,9(43,3)$ & $1,040^{\mathrm{a}} \mathrm{ns}$ & $5,57^{* *}$ \\
Arth_Div & $1,37 \pm 0,04(9,7)$ & $1,24 \pm 0,06(16,2)$ & $1,71 \pm 0,09(16,7)$ & $1,584^{\mathrm{b}} \mathrm{ns}$ & - \\
Wood_Lgth & $1387,5 \pm 108,6(24,7)$ & $1310,0 \pm 74,6(18,0)$ & $702,5 \pm 147,8(66,5)$ & $0,988^{\mathrm{a}} \mathrm{ns}$ & $10,77^{* * *}$ \\
Wood_Dist & $199,5 \pm 6,2(9,8)$ & $71,5 \pm 9,5(42,0)$ & $244,5 \pm 39,8(51,6)$ & $11,31^{\mathrm{a} * * *}$ & $14,02^{* * *}$ \\
Margin_Lgth & $896,0 \pm 137,8(48,6)$ & $933,5 \pm 102,8(34,8)$ & $756,5 \pm 45,9(19,2)$ & $-0,118^{\mathrm{a}} \mathrm{ns}$ & $0,824 \mathrm{~ns}$ \\
Margin_Dist & $234,5 \pm 45,9(61,9)$ & $204,5 \pm 40,5(62,7)$ & $256,0 \pm 65,2(80,5)$ & $0,489^{\mathrm{a}} \mathrm{ns}$ & $0,251 \mathrm{~ns}$ \\
Road_Lgth & $1685,2 \pm 163,4(30,7)$ & $1492,0 \pm 152,8(32,4)$ & $1052,5 \pm 230,4(69,2)$ & $0,864^{\mathrm{a}} \mathrm{ns}$ & $2,058 \mathrm{~ns}$ \\
\hline
\end{tabular}

A LAJTA és MOSON Project területén felmért fürj territóriumok gyomvegetáció átlagos borításértékei alapján domináns fajok voltak az angol perje (Lolium perenne), a csomós ebír (Dactylis glomerata), a francia perje (Arrhenatherum elatius), a szöszös pipitér (Anthemis austriaca) és a tarackbúza (Agropyron repens) is. Az egyes gabonavetések (pl. őszi árpa, öszi búza, tritikálé) a zártabb struktúra és a permetezés folytán kevesebb gyomfajjal, az extenzívebben kezelt mosoni terület kvadrátjai több fajjal rendelkeztek.

A növényzet és az ízeltlábú táplálék diverzitások összehasonlítását szemléltető Rényiféle diverzitási rendezések (2. a-b. ábra) jól mutatják, hogy mind a növényzet, mind pedig a rovarközösségek diverzitása alapján jól elkülönül az extenzív agrárkörnyezet (MOSON Project).
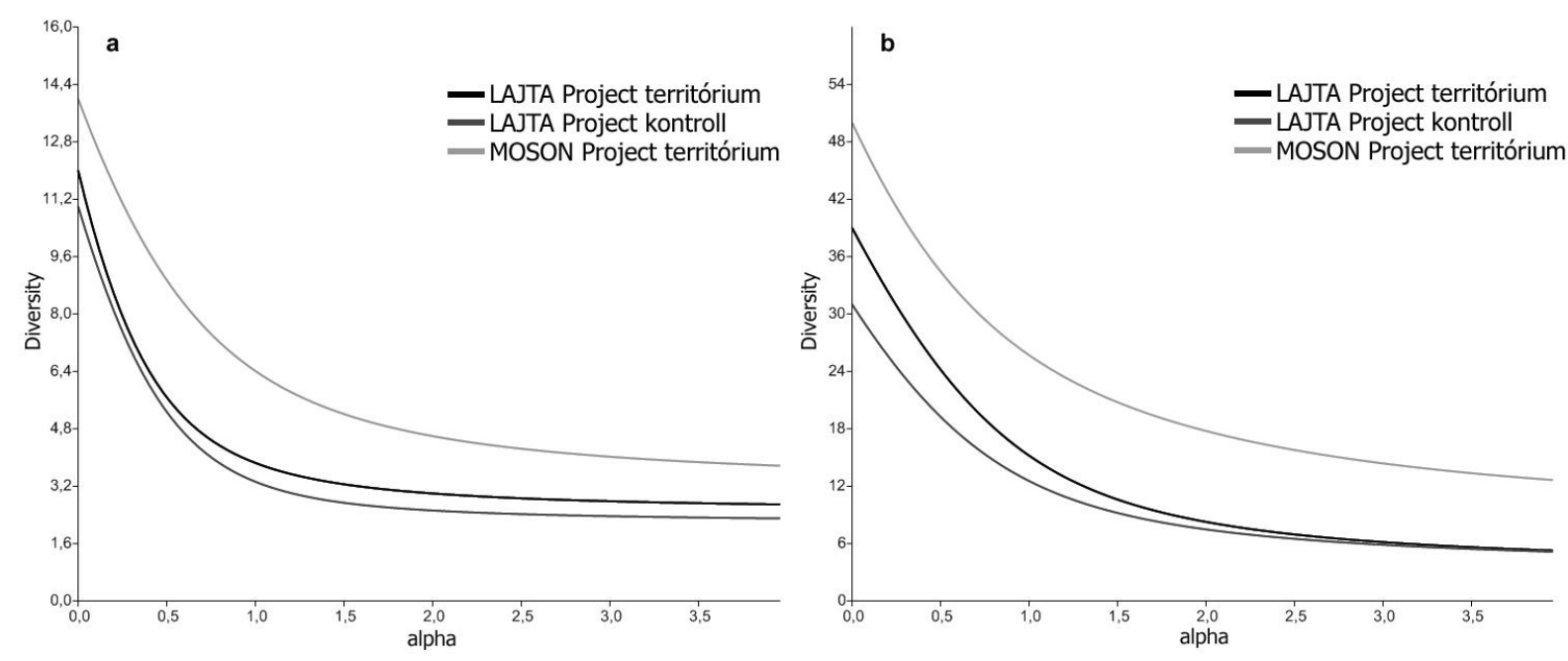

2. ábra: A fürj territóriumok és kontroll pontok diverzitási profiljai a cönológiai felvételezések (a) és a rovarközösségek (b) alapján

Figure 2. Diversity profiles of the Common quail territories and control plots based on the (a) botanical survey and the (b) arthropod communities 
Jól láthatóan az alfa skálaparaméterek teljes spektrumán magasabb értékeket vesznek fel a diverzitási profilok. Az intenzív agrárkörnyezetben felmért foglalt territóriumok és a fürjek által elkerült kontroll mintapontok mind a növényzet, mind pedig a rovardiverzitás tekintetében hasonló, egymáshoz közel futó profilt mutattak. Kisebb eltérés csak a rovarközösségek esetében volt megfigyelhető $\alpha=0$ skálaparaméternél, ami a fürj által foglalt területeken magasabb taxongazdagságot reprezentál.

\subsubsection{Főkomponens-analízis eredményei (LAJTA Project)}

A fökomponens-elemzés input adathalmazát a 2. táblázat változói képezték. A fökomponens-analízis eredményeként összesen négy olyan új, egymástól független változó jött létre, amelynek a sajátértéke 1-nél nagyobb.

A négy komponens a teljes varianciának a 80,5\%-át magyarázza (4. táblázat), ami a vizsgálat szempontjából megfelelő, magas értéknek mondható. A kiválasztott négy főkomponens varimax ortogonális forgatással kapott együtthatóit a 5. táblázat tartalmazza.

$\mathrm{Az}$ első fókomponens (PC1) a variancia 32,11\%-át magyarázta, nagy súllyal tartalmazva a növényzethez kapcsolódó változókat, mint például a borítás (Plant_Cov), fajszám (Plant_S) és diverzitás (Plant_Div). Emellett jól korrelált még ezzel a fökomponenssel az ízeltlábú abundancia (Arth_Ind), valamint a legközelebbi erdősávtól mért távolság (Wood_Dist) is. Az átlagos fökomponens-szkórok e tengely mentén szignifikáns különbséget mutattak a tényleges territóriumok és a fürjek által nem foglalt, kontroll mintakörök között ( $t$ test, $t=5,023 ; p<0,01$ ).

A második főkomponens (PC2) a variancia 20,97\%-át fedte le, és nagy súllyal tartalmazta az ízeltlábú táplálékkínálathoz kapcsolódó további változókat, mint a száraz tömeg (Arth_W), valamint az ízeltlábú közösségek diverzitása (Arth_Div). Közepes erősségü korrelációval szerepet játszik ennél a fökomponensnél a gyepes táblaszegélyek összhossza (Margin_Lgth) is. Az átlagos fökomponens-szkórok azonban nem mutattak szignifikáns eltérést a territóriumok és a kontrollpontok között a második fökomponens mentén ( $\mathrm{t}$ test, $\mathrm{t}=$ $0,892 ; \mathrm{ns})$.

\section{4. táblázat: A komponensekhez tartozó sajátértékek és a teljes varianciának a komponensekkel magyarázott hányadai (LAJTA Project)}

Table 4. Eigenvalues of components and total variance explained by components

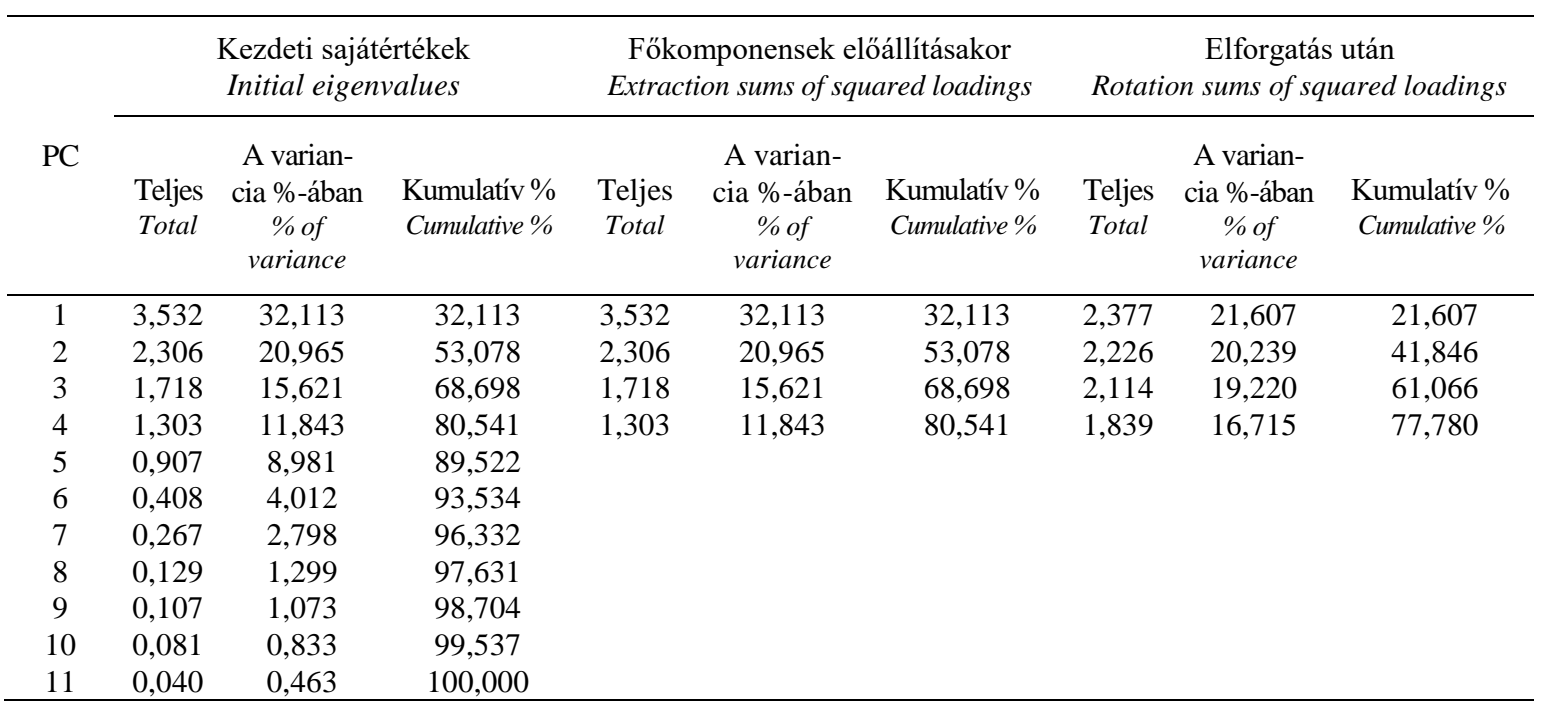


A harmadik főkomponens (PC3) a variancia további 15,62\%-áért volt felelös, és elsősorban az erdősávok összesített hossza (Wood_Lgth), valamint a gyepes táblaszegélyektől való távolság (Margin_Dist) határozta meg. A foglalt territóriumok és a kontrollpontok között viszont nem mutatkozott szignifikáns elkülönülés e fökomponens mentén ( $t$ test, $t=1,873$; ns).

\section{5. táblázat: A komponens-együtthatók mátrixa varimax forgatás után}

Table 5. Varimax rotated component matrix

\begin{tabular}{lcccc}
\hline & \multicolumn{4}{c}{ Fökomponens - Principal components } \\
\cline { 2 - 5 } & PC1 & PC2 & PC3 & PC4 \\
\hline Plant_S & $\mathbf{0 , 5 1 4}$ & 0,183 & 0,319 & 0,264 \\
Plant_Div & $\mathbf{0 , 6 0 3}$ & $-0,098$ & 0,290 & $-0,119$ \\
Plant_Cov & $\mathbf{0 , 8 6 3}$ & 0,244 & $-0,180$ & 0,096 \\
Arth_Ind & $\mathbf{0 , 6 6 7}$ & 0,340 & $-0,187$ & 0,022 \\
Arth_W & $-0,231$ & $\mathbf{0 , 8 0 1}$ & $-0,196$ & $-0,231$ \\
Arth_Div & $-0,214$ & $\mathbf{0 , 8 7 0}$ & 0,144 & 0,097 \\
Wood_Lgth & 0,311 & $-0,372$ & $\mathbf{0 , 7 9 6}$ & 0,159 \\
Wood_Dist & $\mathbf{- 0 , 6 9 6}$ & $-0,313$ & 0,134 & 0,221 \\
Margin_Lgth & 0,319 & $\mathbf{0 , 5 7 6}$ & 0,276 & $-0,202$ \\
Margin_Dist & $-0,361$ & $-0,344$ & $-\mathbf{0 , 6 2 5}$ & $-0,033$ \\
Road_Lgth & 0,193 & $-0,209$ & 0,220 & $-\mathbf{0 , 6 7 8}$ \\
\hline
\end{tabular}

A negyedik fökomponens (PC4) a variancia 11,84\%-át írta le, nagy súllyal csupán a mintakörökön belül mért összesített úthosszat (Road_Lgth) tartalmazva. Mindazonáltal az átlagos főkomponens-szkórok ennél a fókomponensnél sem mutattak szignifikáns eltérést a fürj territóriumok és a kontroll pontok között ( $t$ test, $t=1,516$; ns).

A továbbiakban a főkomponens-analízis során kapott új, egymástól független változók előrehaladó lépésenkénti szelekcióval (forward stepwise) kerültek be az általánosított lineáris modellekbe (GLMs), amelynek összefoglaló eredményeit a 6. táblázat tartalmazza.

6. táblázat: Az általánosított lineáris modell (GLMs) eredménye a fürj jelenlétének predikciójára Table 6. Summary of GLMs for the probability of presence of Common Quail

\begin{tabular}{lcccc}
\hline Faktorok - Factors & $\boldsymbol{\beta}$ & $\mathbf{S E}$ & $\chi^{2}$ & $\mathbf{p}$ \\
\hline (intercept) & 2,018 & 0,747 & 7,114 & 0,008 \\
PC1 & 0,076 & 0,017 & 34,073 & 0,000 \\
PC3 & $-0,625$ & 0,210 & 3,988 & 0,047 \\
Residual deviance & 17,963 & & & \\
\hline
\end{tabular}

A táblázat csak a szignifikáns hatású változókat tünteti fel. Az első főkomponens (PC1), így az azt meghatározó eredeti faktorok (növényzet változói, ízeltlábú egyedszám, fás ökotonoktól való távolság) pozitív hatással voltak a fürj jelenlétének valószínúségére $(\beta=0,076)$. Egyben ez a fökomponens volt a legerősebben befolyásoló változó a modellben $\left(\chi^{2}=34,073\right)$.

A harmadik főkomponens (PC3), illetve az azt meghatározó változók (fás ökotonok hossza, táblaszegélytől való távolság) kevésbé voltak meghatározók $\left(\chi^{2}=3,988\right)$, de szintén szignifikáns hatással bírnak a fürjek jelenlétének valószínüségére. A kapott modell jobb illeszkedést mutatott a fürj fészkelőhabitat előrejelzésére a jelenlét esetében (70,4\%), összehasonlítva a helyesen besorolt esetek arányát a nem foglalt (hiány), kontroll habitatok 
vonatkozásában (62,6\%). A GLMs modell validitását vizsgálva a Cohen-féle kappa érték 0,441-nek adódott, ami közepes illeszkedést jelent az adatokhoz.

\subsubsection{Főkomponens-analízis eredményei (LAJTA és MOSON Project)}

Ahhoz, hogy teljesebb képet tudjunk alkotni a fürj élőhelyválasztásáról, az extenzívebben kezelt MOSON Project területén felmért territóriumok élöhelyi paramétereit is bevontuk a vizsgálatokba. Az így lefuttatott fökomponens-analízis eredményeként három olyan, egymástól független változó jött létre, amelynek a sajátértéke 1-nél nagyobb. A három komponens a teljes varianciának több, mint kétharmadát $(70,6 \%)$ magyarázza, ami az értékelés szempontjából megfelelőnek mondható (7.táblázat). A három főkomponens varimax ortogonális forgatással kapott együtthatóit a 8. táblázat tartalmazza.

Az első főkomponens (PC1) a variancia 41,01\%-át magyarázta. A MOSON Project területeivel kibővített elemzésben hasonlóképpen nagy súllyal szerepelnek a növényzeti változók: a fajszám (Plant_S), diverzitás (Plant_Div) és borítás (Plant_Cov). Az ízeltlábú táplálékkínálatot jellemző változók közül itt a diverzitás (Arth_Div), valamint a száraz tömeg (Arth_W) mutattak erősebb korrelációt az első főkomponenssel. Az átlagos fökomponensszkórok szignifikáns különbséget mutattak az első fökomponens tengelye mentén (egytényezős ANOVA, $\mathrm{F}(2,39)=32.68 ; \mathrm{p}<0,01$ ).

A második fökomponens (PC2) a variancia további 17,14\%-át fedte le, nagy súllyal ennél a fökomponensnél az ízeltlábú egyedszám (Arth_Ind), a szegélyökotonoktól való távolság (Wood_Dist, Margin_Dist), valamint az erdősávok hossza (Wood_Lgth) változók jelentek meg. Az átlagos fökomponens-szkórok e tengely mentén is szignifikáns különbséget mutattak (egytényezős ANOVA, $\mathrm{F}(2,39)=4,71 ; \mathrm{p}<0,05)$.

A táblaszegélyek (Margin_Lgth) és az utak hossza (Road_Lgth) által leginkább meghatározott harmadik fökomponens (PC3) a variancia 12,38\%-át magyarázta, azonban nem mutatkozott szignifikáns eltérés az átlagos fökomponens-szkórok között (egytényezös ANOVA, $\mathrm{F}(2,39)=0,63 ; \mathrm{p}=0,446 ; \mathrm{ns})$.

\section{7. táblázat: A komponensekhez tartozó sajátértékek és a teljes varianciának a komponensekkel magyarázott hányadai}

Table 7. Eigenvalues of components and total variance explained by components

\begin{tabular}{|c|c|c|c|c|c|c|c|c|c|}
\hline 2 & 1,660 & 17,142 & 58,211 & 1,660 & 15,088 & 54,658 & 2,106 & 19,145 & 51,182 \\
\hline 3 & 1,134 & 12,384 & 70,595 & 1,134 & 10,312 & 64,969 & 1,517 & 13,787 & 64,969 \\
\hline 4 & 0,994 & 8,364 & 78,959 & & & & & & \\
\hline 5 & 0,868 & 6,002 & 84,961 & & & & & & \\
\hline 6 & 0,683 & 4,812 & 89,773 & & & & & & \\
\hline 10 & 0,071 & 0,489 & 99,616 & & & & & & \\
\hline 11 & 0,042 & 0,384 & 100,000 & & & & & & \\
\hline
\end{tabular}


8. táblázat: A komponens-együtthatók mátrixa varimax forgatás után

Table 8: Varimax rotated component matrix

\begin{tabular}{lccc}
\hline & \multicolumn{3}{c}{ Fökomponens - Principal components } \\
\cline { 2 - 4 } & PC1 & PC2 & PC3 \\
\hline Plant_S & $\mathbf{0 , 9 1 6}$ & 0,120 & $-0,129$ \\
Plant_Div & $\mathbf{0 , 8 0 7}$ & 0,136 & $-0,258$ \\
Plant_Cov & $\mathbf{0 , 8 7 7}$ & 0,365 & $-0,068$ \\
Arth_Ind & 0,174 & $\mathbf{0 , 5 9 3}$ & $-0,048$ \\
Arth_W & $\mathbf{0 , 6 5 3}$ & 0,461 & 0,071 \\
Arth_Div & $\mathbf{0 , 7 5 3}$ & $-0,122$ & $-0,178$ \\
Wood_Lgth & $-0,200$ & $\mathbf{- 0 , 6 2 9}$ & $-0,030$ \\
Wood_Dist & 0,290 & $\mathbf{0 , 6 3 7}$ & $-0,326$ \\
Margin_Lgth & $-0,124$ & 0,281 & $\mathbf{0 , 8 4 9}$ \\
Margin_Dist & 0,246 & $\mathbf{- 0 , 5 7 0}$ & $-0,165$ \\
Road_Lgth & $-0,198$ & $-0,395$ & $\mathbf{0 , 7 3 2}$ \\
\hline
\end{tabular}

\subsubsection{Diszkriminancia-analízis eredményei (LAJTA és MOSON Project)}

A diszkriminancia-analízis segítségével arra a kérdésre kerestük a választ, hogy mutatkozik-e eltérés intenzív és extenzív agrárkörnyezetben a fürj habitatválasztásában. Az analízisbe a LAJTA Project kontrollpontjait is bevontuk. Összesen három diszkrimináló függvény jött létre a 42 felmért mintakör élöhelyjellemzőinek analízise során. A diszkrimináló függvények standardizált együtthatóinak értékeit a 9. táblázat tartalmazza. Az első diszkrimináló függvényt legerösebben a növényzet borítása (Plant_Cov) határozza meg, ezután következik az erdősávoktól való távolság (Wood_Dist), valamint az erdősávok hossza (Wood_Lgth). Szükséges ellenőrizni, hogy az eljárás olyan diszkrimináló függvényeket hozott létre, amelyek értékei a legnagyobb mértékben eltérnek a vizsgált intenzív és extenzív fészkelöhelyek, valamint a kontroll élőhelyek között. Ezt mutatják a Wilks' Lambda-teszt értékei és a kapcsolódó szignifikanciák (10. táblázat).

9. táblázat: A kanonikus diszkriminancia függvények standardizált együtthatói

Table 9: Standardized canonical discriminant function coefficients

\begin{tabular}{lccc}
\hline & \multicolumn{3}{c}{ Diszkrimináló függvény } \\
\cline { 2 - 4 } & DF1 & DFcriminant function \\
\hline Plant_S & $-0,061$ & $\mathbf{- 0 , 6 3 8}$ & DF3 \\
Plant_Div & 0,369 & $\mathbf{0 , 8 7 9}$ & $-0,066$ \\
Plant_Cov & $\mathbf{0 , 9 6 3}$ & $-0,313$ & $-0,160$ \\
Arth_Ind & 0,115 & $\mathbf{0 , 8 5 1}$ & 0,475 \\
Arth_W & $-0,464$ & 0,015 & 0,176 \\
Arth_Div & 0,392 & $\mathbf{0 , 6 2 3}$ & $-0,277$ \\
Wood_Lgth & $\mathbf{0 , 6 9 5}$ & 0,318 & 0,030 \\
Wood_Dist & $\mathbf{- 0 , 9 4 6}$ & 0,438 & $-0,114$ \\
Margin_Lgth & $-0,190$ & $-0,005$ & $-0,243$ \\
Margin_Dist & 0,236 & 0,497 & 0,172 \\
Road_Lgth & 0,360 & 0,931 & $\mathbf{0 , 7 3 1}$ \\
\hline
\end{tabular}


Az első teszt (1-től 3-ig) esetében - a mindhárom diszkrimináló függvény által együttesen magyarázatlanul hagyott négyzetösszeget a függvények teljes heterogenitását jelentő négyzetösszeghez viszonyítva - az eredmények azt mutatják, hogy az élőhelyeket leíró folytonos változók együttes hatása alapján az extenzív és intenzív agrárélőhelyek - utóbbin belül pedig a fészkelőhelyek és kontroll mintaterületek is -, szétválnak egymástól (Wilks teszt: $\lambda=$ 0,003, $\chi^{2}=409,994 ; p<0,0001$ ), és a csoportok centroidjai közötti különbség szignifikáns.

A következő teszt (2-től 3-ig) azt vizsgálja, hogy az első függvényt kihagyva a modellből a többi diszkrimináló függvény a teljes heterogenitás mekkora részét hagyja magyarázatlanul. Fokozatosan kihagyva a többi függvényt is az elemzésből, a további tesztekből arra az eredményre jutunk, hogy mindegyik variáció szignifikáns különbséget ad a jellemzők között, bár az utolsó teszt esetében (egyedül a 3. diszkrimináló függvényt véve) a diszkrimináló erő már láthatóan kisebb.

\section{0. táblázat: A diszkrimináló függvények tesztje \\ Table 10. Tests of the discriminal functions}

\begin{tabular}{lcccc}
\hline $\begin{array}{l}\text { Függvény-teszt } \\
\text { Test of Function }\end{array}$ & $\begin{array}{c}\text { Wilks' } \\
\text { Lambda }\end{array}$ & Chi $^{2}$ & df & Sig. \\
\hline 1-töl 3-ig & 0,003 & 409,994 & 12 & 0,000 \\
2-töl 3-ig & 0,046 & 80,215 & 6 & 0,000 \\
3 & 0,346 & 27,580 & 2 & 0,000 \\
\hline
\end{tabular}

A sajátértékek a diszkrimináló függvények által megmagyarázott és megmagyarázatlanul hagyott heterogenitás hányadosai (11. táblázat). A táblázatból az is kiolvasható, hogy a teljes megmagyarázott hányadot 100\%-nak tekintve az egyes diszkrimináló függvények hogyan osztoznak ezen a magyarázaton. Látható, hogy a megmagyarázott hányad legnagyobb részben $(77,7 \%)$ az első, leginkább a növényzet borítása, valamint a fás ökotonok hossza, illetve az azoktól való távolság által meghatározott diszkrimináló függvénynek köszönhető. A diszkriminancia-analízis a változók alapján a felmért pontokat három jól elkülöníthető diszkrét csoportba sorolta, a helyesen besorolt esetek aránya 96,7\%-nak adódott. A 3. ábra ezt a három csoportot szemlélteti az első két diszkrimináló függvény által meghatározott kétdimenziós térben. Az intenzív (LAJTA Project) és extenzív (MOSON Project) élőhelyek határozott elkülönülést mutattak.

\section{1. táblázat: A diszkrimináló függvények értelmezett varianciája (DA)}

Table 11. Total variance explained (DA)

\begin{tabular}{ccccc}
\hline Függvény & Sajátérték & $\begin{array}{c}\text { A variancia } \\
\% \text {-ában }\end{array}$ & $\begin{array}{c}\text { Kumulatív } \\
\%\end{array}$ & $\begin{array}{c}\text { Kanonikus } \\
\text { korreláció }\end{array}$ \\
\hline 1 & 6,572 & 77,7 & 77,7 & 0,932 \\
2 & 2,865 & 17,9 & 95,6 & 0,809 \\
3 & 1,102 & 4,4 & 100,0 & 0,737 \\
\hline
\end{tabular}

A LAJTA Project területén belül, a fürj territóriumok és a kontroll mintapontok között kisebb átfedés ugyan mutatkozik az első két diszkrimináló függvény által meghatározott síkon, a csoportok centroidjai közötti szignifikáns különbség azonban azt mutatja, hogy a foglalt és kontroll élőhelyek is jól szétválnak egymástól az első három diszkrimináló függvény által meghatározott topológiai térben. 


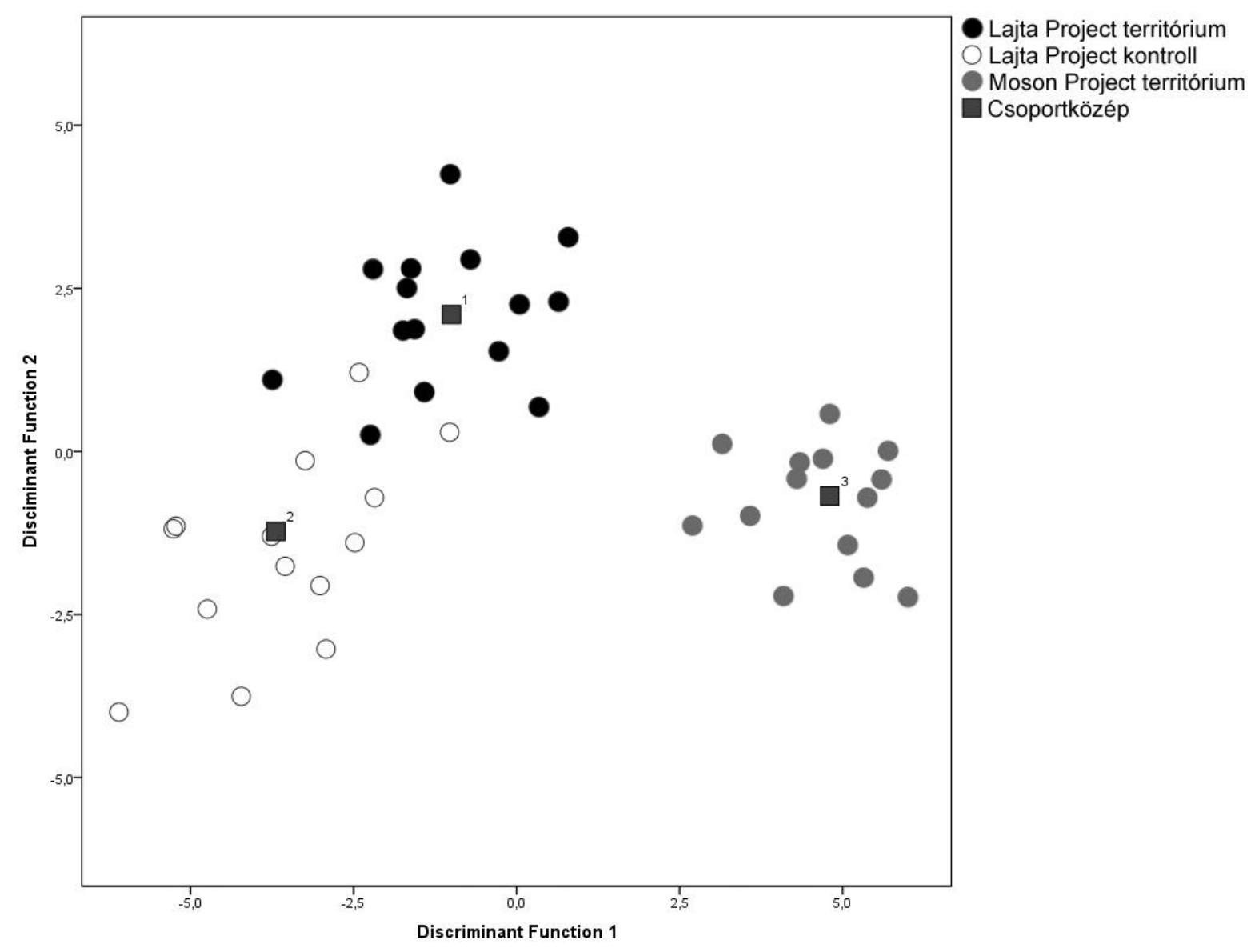

\section{3. ábra: Fürj territóriumok és kontroll pontok diszkriminancia topológiája az élőhelyváltozók alapján létrejött függvények szerint}

Figure 3: Discriminant function analysis scatterplot of Common quail territories and control plots

\section{DISZKUSSZIÓ}

Az agrárélőhely uniformizálásának hatása (STOATE et al. 2001, ROBINSON \& SUTHERLAND 2002) vizsgálatunk egyes részeredményeiben is megmutatkozik, így a növényzet fajszáma a MOSON Project területén szignifikánsan magasabb, mint a lajtai területeken. De ide sorolhatjuk az ízeltlábú egyedszámbeli eltéréseket is, amire már Európában korábban felhívták a figyelmet (WILSON et al. 1999). A LAJTA Project területén két kulcsfontosságú környezeti tényezö, a megfelelő vegetációborítás és táplálékkínálat, pozitívan befolyásolja a faj előfordulását. Ez a két feltétel nemcsak a fürjek számára fontos, hanem további mezei madárfajoknak is, mint például a fogoly vagy a mezei pacsirta, de az utóbbi tényező a rovarevő emlösöknél sem elhanyagolható. Az optimális lágyszárú növényzet ellenállóbb az időjárás viszontagságaival és biztonságosabb a ragadozókkal szemben, ezáltal alkalmas fészkelöhelyet biztosít a földön fészkelö fajok számára (RANDS 1986, GREEN \& STOWE 1993, EGGERS et al. 2011). CAPDEVILA et al. (2016) szerint a fürjek esetében (is) kimondottan fontos tényező a növényzet magassága, mivel a magasabb vegetációban a fürj kevésbé válik láthatóvá a ragadozók számára. Ezt a tényt erösítik RoDRíGUEZ-TEIJEIRO et al. (2010) és NÉMETH \& WINKLER (2017) vizsgálatai is, miszerint a fürjek a betakarítás vagy kaszálás időszakában a területet elhagyva egy új, megfelelő magasságú vegetációval rendelkező helyszínt, búvóhelyet keresnek. Ahogy azt már korábban többen is kijelentették (pl. GEORGE 
1990, Broyer 1996, Michailov 1996, Aunins \& PRIEDNiEKS 2003, KosicKi et al. 2014), a fürjek egyáltalán nem kerülik a nagy kiterjedésü mezőgazdasági élöhelyeket. MOREBY \& AEBISCHER (1992) és PANEK (1997) véleménye megegyezik abban, hogy az egybefüggő növényzetborítás pozitív hatással van a rovarmennyiség növekedésére, ami a szárnyas apróvad fiókák (pl. fácán (Phasianus colchicus), fogoly) elsődleges tápláléka, hozzájárulva ezáltal a szaporodási sikerességhez is. SIEMANN et al. (1998) és KLEIJN et al. (2006) munkáikban arra hívták fel a figyelmet, hogy a növényzet fajszámának gazdagsága szoros kapcsolatban van számos ízeltlábú csoporttal. Mindkét kutatócsapat arra az eredményre jutott, hogy a növényi fajgazdagság pozitív hatással bír, azaz növeli az egyes rovarcsoportok (pl. Orthoptera, Araneida, Coleoptera, Hymenoptera) fajgazdagságát mind a gyepterületeken, mind pedig a mezőgazdasági területeken. Vizsgálatunkban a rovardiverzitásban nem adódott különbség a territóriumok és kontroll területek között, viszont a Rényi-féle diverzitási rendezés megmutatta a LAJTA és MOSON Project rovarközösségeinek diverzitása között fennálló eltérést.

A táplálékkínálat-vizsgálat eredménye tehát azt mutatja, hogy az ízeltlábúak abundanciája meghatározó szereppel bír a faj élőhelyválasztásakor, az ízeltlábúak diverzitása azonban csak csekélyebb mértékben befolyásolhatja a fürjeket. Habár szezonális eltérés tapasztalható a faj táplálkozásában (GÁL \& MAROSÁN 2008), mégis a gerinctelen fajok jelentős arányt képviselnek a fürjek táplálékában, különösen a költési időszak alatt (KEVE et al. 1953, COMBREAU \& GUYOMARC'H 1992). Mivel a kikelés utáni első hetekben a fiatalok csak és kizárólag gerinctelen állatfajokkal táplálkoznak, növekedésüket nagyban befolyásolja ennek a tápláléknak az elérhetősége (COMBREAU \& GUYOMARC'H 1989, GUYOMARC'H et al. 1998a). A fürjek az állati táplálék mellett különböző magvakat is fogyasztanak, így a vegetáció borítása mellett a lágyszárú diverzitásának is nagy szerepe van a LAJTA Project területén, ahogy azt a fökomponens-analízis is kimutatta. A müvelt gabonatáblák - ahol a legtöbb fürj territórium található -, általában kevesebb magforrást biztosítanak a madarak számára, mint a táblaszegélyek (WILSON et al. 1999, VICKERY et al. 2002, HOLLAND et al. 2012). Mindemellett a LAJTA Project területén néhány növényi kultúra (pl. őszi gabonák) megfelelő vegetációborítással és fajgazdagsággal rendelkezett, a táblaszegélyek kedvezőbb állapotát azonban nem érték el. Spanyol telemetriás vizsgálat (CAPDEVILA et al. 2016) alapján a fürj tojók inkább a táblaszegélyekhez közel vagy a táblaszegélyekben raktak fészket, ami a biztonságosabb borítással és a jobb táplálékmennyiséggel hozható összefüggésbe (THOMAS \& MARSHALl 1999, ViCKERY et al. 2002, Holland et al. 2012). Azonban FARAGÓ (2018) Kisalföldön (ideértve a LAJTA és MOSON Project területein is) végzett hosszútávú vizsgálataiból azt a következtetést vonta le a táplálékforrás tekintetében, hogy a szántóföldi élőhelyek nem sokkal maradnak el a természetszerü gyepterületektől, így a fürj számára ez a tápláléktípus a nagyobb táblákban is biztosított. Másrészröl több kutatás azt hangsúlyozza, hogy a táblaszegélyekben nagyobb predációs nyomással kell szembesülni (pl. PATON 1994, GARDNER 1998, SARGENT et al. 1998, BATÁRY \& BÁLDI 2004), de ha a cserje- és/vagy erdősáv eltávolításra kerül a határáról, akkor a következő években egyes madárfajok fészekdenzitása megnő az egykori szegélyek mentén (ELLISON et al. 2013). Negatív szegélyhatást a fürjnél a korábbi spanyol kísérlet azonban nem talált (CAPDEVILA et al. 2016). A tájléptékü változók közül viszont a legközelebbi fás ökotontól való távolság mutatott szignifikáns különbséget a territóriumok (mindkét projektterületnél) és kontrollhelyek között. A mosoni területnél azért is nagyobb ez a távolság, mivel arányaiban kevesebb a cserje- és erdősáv, mint a lajtai területnél. De feltételezhetően a korábban említett nagyobb predációs nyomás is közrejátszhat abban, hogy az erdősávoktól viszonylag nagyobb távolságra voltak az észlelések. Annak ellenére, hogy van megfelelő szárnyas- és szőrmés ragadozógyérítés a területen, ezekben az erdősávokban is - mint azt Európa más tájain megfigyelték (pl. PATON 1994, HUHTA et al. 
1996) - a dolmányos varjú (Corvus cornix), szarka (Pica pica) és nyest (Martes foina) fészekrabló hatása jelentkezhet leginkább, de az utóbbi években feltételezhető a megnövekedett holló (Corvus corax) állomány predációs nyomása is.

A gyepes sávok fontossága mellett korábbi kutatások (pl. HINSLEY \& BELLAMY 2000, BATÁRY et al. 2010, FARAGÓ et al. 2012, MORELLI 2013) bizonyos mezei madárfajok esetében a fás ökotonok (pl. telepített sövények, bokorsávok vagy mezővédő erdősávok) szerepét emelik ki. Mivel a MOSON Project területén az erdő- és bokorsávok területaránya alacsonyabb (kb. 30 ha), mint a LAJTA Project területén (kb. 120 ha), ezért nem meglepö, hogy a fás ökotonokat érintő összehasonlításnál az értékek szignifikánsan eltérnek a MOSON Project esetében, illetve az azoktól való távolság is jelentősen kiugró. Az eredményekből jól látszik, hogy a fürj az erdősávok közelségét kerüli és inkább a szegélyektől távolabb, a táblák belseje felé található meg, amely összhangban van korábbi, hasonló élőhelyeken végzett kutatásokkal (PANEK 1998, PERENNOU 2009). A LAJTA Project területén lévő fás ökotonhálózatról bebizonyosodott, hogy nem elhanyagolható a hatása a fürj élőhelyválasztására, akár, mint lehetséges táplálékbázist biztosító hely, mivel FOURNIER \& LOREAU (2001) szerint a futóbogarak (Carabidae) gyüjtőhelyévé is válhat. MoRELLI (2013) a nagytáblás szántók folytonosságának megtörését is kiemeli, így akár az ökológiai folyosók szerepét is betölthetik. Továbbá a fürj mellett más fajok is hasznát láthatják az ilyen élőhelyeknek, mint például a fogoly, kis örgébics, tövisszúró gébics (Lanius collurio), örvös galamb (Columba palumbus) vagy erdei fülesbagoly (Asio otus) is. A két projekt területén végzett terepi megfigyeléseink, valamint korábbi kutatások alapján a cserje- és erdősávok a fogolynak menedéket nyújthatnak (BRO et al. 2000), a Lanius fajoknál kiülö- és költőhelyet is biztosíthatnak (WIRTITSCH et al. 2001, BRAMBILlA et al. 2010, MORELLI et al. 2012), a további említett fajok pedig szintén költőhelyet találhatnak bennük. Ezenkívül Nyugat- és Észak-Európa területéről is ismertek olyan felmérések (pl. BERG \& PÄRT 1994, GREEN et al. 1994, Hinsley \& BELlAMY 2000, BATÁRY et al. 2010, MoRELli 2013), amelyek szerint az ilyen fás ökotonok megörzése vagy akár telepítése, az agrárkörnyezet fejlesztéseként, pozitív hatással van a mezei madárfajok diverzitására és abundanciájára is.

Ha a fökomponens-elemzés értékeit nézzük meg, a fentebb említett tényezők mellett még a növényzet diverzitása és az ízeltlábúak abundanciája voltak azok, ahol különbség adódott az territórium léptéken belül. Az extenzíven és az intenzíven kezelt területek közötti különbség (ld. diszkriminancia-analízis), illetve elkülönülés nem volt rendkívüli a terepi tapasztalatok alapján, de az elemzések eredménye egyértelmüvé tette a feltételezett eltérést. Ez az eredmény mindazonáltal igazolja a korábbi európai vizsgálatokat, amely alapján az intenzívebb mezőgazdasági müvelés az ízeltlábúak csökkenését vonja maga után (SIEMANN et al. 1998, BENTON et al. 2002). Habár fás ökonotok tekintetében a mosoni terület alulmaradt (részben veszítve ezek rovarokra gyakorolt pozitív hatásából), de a kaszálás után meghagyott búvósávok vagy a kevésbé pontos kaszálásnak köszönhetően megmaradt táblaszegélyek az ízeltlábúaknak is fontos menedéket és táplálkozást biztosítanak (ANDERSEN 1997, VISZLÓ 2007, HUMBERT et al. 2012). Mindemelett SCHAFFERS et al. (2008) szerint a rovarközösségek összetételét és diverzitását a növényi fajösszetétel befolyásolja leginkább, mivel a vegetáció fajösszetételében integrálódik és szintetizálódik számos okozati tényező, amelyek a vizsgált ízeltlábú csoport (pl. növényevő, ragadozó, viráglátogató) számára egyaránt fontosak. Maradva a táplálékmennyiség kérdésénél, jól mutatja a kezelés fontosságát a fogoly fészekalj vizsgálata (RANDS 1986), amely szerint azokon a területeken, ahol kevésbé intenzív körülmények voltak, a fogoly párok nagyobb fészekaljat költöttek és a fiókák túlélése is sikeresebb volt. Így ilyen helyeken, mint a MOSON Project területe, hasonló eset állhat fenn a vadászható szárnyas apróvad és védett mezei madárfajainknál is (pl. fácán, fogoly, fürj, mezei pacsirta, sordély, túzok). 
A LAJTA Project területén végzett vizsgálatból egyértelműen látszik, hogy a fürj szívesen használja a nagytáblás mezőgazdasági területeket, amelyeket, mint intenzív agrárkörnyezet szokás jellemezni. Tehát a megfelelő vegetációstruktúra - magas és elegendően sűrü, állandó/egybefüggő borítás - megléte inkább pozitív, mint gátló hatással bír a mezei madárfajok számára (ERDŐS et al. 2009, EGGERS et al. 2011), amelyet jelen vizsgálat is megerősít a fürj esetében.

\section{KÖSZÖNETNYILVÁNÍTÁS}

Jelen publikáció az „EFOP-3.6.1-16-2016-00018 - A felsőoktatási rendszer $K+F+I$ szerepvállalásának növelése intelligens szakosodás által Sopronban és Szombathelyen" címü projekt támogatásával valósult meg.

\section{IRODALOMJEGYZÉK}

ANDERSEN, A. (1997): Densities of overwintering carabids and staphylinids (Col., Carabidae and Staphylinidae) in cerealand grass fields and boundaries. Journal of Applied Entomology 121(1-5): 77-80. https://doi.org/10.1111/j.1439-0418.1997.tb01374.x

AUNINS, A. \& PRIEDNIEKS, J. (2003): Bird population changes in Latvian farmland, 1995-2000: responses to different scenarios of rural development. Ornis Hungarica 12-13: 41-50.

BÁLDI, A. \& BATÁRY, P. (2011): The past and future of farmland birds in Hungary. Bird Study 58(3): 365-377. https://doi.org/10.1080/00063657.2011.588685

BÁLDI, A. \& FARAGÓ, S. (2007): Long-term changes of farmland game populations in a postsocialist country (Hungary). Agriculture, Ecosystems \& Environment 118(1-4): 307-311. https://doi.org/10.1016/j.agee.2006.05.021

BÁLDI, A. (2008): Az agrárgazdálkodás változásának hatása madarakra: európai és hazai körkép [The effects of changes in agriculture on birds: a review for Europe and Hungary]. Ornis Hungarica 15-16: 75-75.

BÁN, T. \& IGMÁNDY, J. (1939): Hajdúnánás fészkelő madarai [Breeding birds of Hajdúnánás]. Aquila 42-45: 669-671. (in Hungarian)

BARBER, H. S. (1931): Traps for cave inhabiting insects. Journal of the Elisha Mitchell Scientific Society 46(2): 259-266.

BARTHOS, GY. (1917): Adatok a fürj magassági elterjedéséhez [Data on the distribution of Quail]. - Aquila 24: 276. (in Hungarian)

BATÁRY, P. \& BÁLDI, A. (2004): Evidence of an edge effect on avian nest success. Conservation Biology 18(2): 389-400. https://doi.org/10.1111/j.1523-1739.2004.00184.X

BAtÁRY, P., MAtThiEsen, T. \& TscharntKe, T. (2010): Landscape-moderated importance of hedges in conserving farmland bird diversity of organic vs. conventional croplands and $\begin{array}{llll}\text { grasslands. } & \text { Biological } & \text { Conservation } & \text { 143(9): }\end{array}$ https://doi.org/10.1016/j.biocon.2010.05.005

BERG, Å. \& PÄRT, T. (1994): Abundance of breeding farmland birds on arable and set-aside fields at forest edges. Ecography 17(2): 147-152. https://doi.org/10.1111/j.16000587.1994.tb00087.x

BeYER, H. L. (2004): Hawth's Analysis Tools for ArcGIS. Download: http://www.spatialecology.com/htools.

BirdLife InTERnATIONAL (2018): Species factsheet: Coturnix coturnix. - Downloaded from http://www.birdlife.org on 30/09/2018.

Brambilla, M., Casalea, F., Bergeroa, V., Boglianic, G., Crovettoa, M., Falcoa, R., RoATIE, M. \& NegRIC, I. (2010): Glorious past, uncertain present, bad future? Assessing 
effects of land-use changes on habitat suitability for a threatened farmland bird species. Biological Conservation 143(11): 2770-2778. https://doi.org/10.1016/j.biocon.2010.07.025

BROYER, J. (1996): Les "fenaisons centrifuges", une méthode pour réduire la mortalité des jeunes râles de genêts Crex crex et des cailles des blés Coturnix coturnix. Revue d'Écologie 51(3): 269-276.

Capdevila, J., Puigcerver, M., LóPez, S., Pérez-Masdeu, E., García-Galea, E. \& RodríGuezTEIJEIRO, J. D. (2016): The role of nest site selection and cereal production in differential nest predation in Common Quail Coturnix coturnix and hybrid quail C. coturnix x C. japonica. Ibis 158(4): 784-795. https://doi.org/10.1111/ibi.12390

Chamberlain, D. E. \& FulleR, R. J. (2000): Local extinctions and changes in species richness of lowland farmland birds in England and Wales in relation to recent changes in agricultural land-use. Agriculture, Ecosystems \& Environment 78(1): 1-17. https://doi.org/10.1016/S0167-8809(99)00105-X

CoHEN, J. (1960): A coefficient of agreement for nominal scales. Educational \& Psychological Measurement 20(1): 37-46.

Combreau, O. \& GuYOMARC'H, J. C. (1989): Évolution de la sélectivité alimentaire chez la caille des blés captive en période estivale. Cahiers d'Éthologie Appliquée 9(3): 321-338.

Combreau, O. \& GuYOMARC'H, J. C. (1992): Energy intake, breeding success and growth in captive European quail (Coturnix coturnix coturnix) in relation to diet. Gibier Faune Sauvage 9: 677-692.

CRAMP, S. (1980): Handbook of the Birds of Europe, the Middle East and North Africa: The Birds of Western Palearctic, Oxford University Press. Vol. II. 496-503.

Debreceni, Ö., Drozd, A., György, I. \& Urbán, S. (1990): Áttelelö fürj (Coturnix coturnix) Jászkarajenő határában. Madártani Tájékoztató júl-dec.: 25.

Donald, P. F., Green, R. E. \& HeAth, M. F. (2001): Agricultural intensification and the collapse of Europe's farmland bird populations. Proceedings of the Royal Society B 268(1462): 2529. https://doi.org/10.1098/rspb.2000.1325

Donald, P. F., SANDERSON, F. J., Burfield, I. J. \& VAN Bommel, F. P. J. (2006): Further evidence of continent-wide impacts of agricultural intensification on European farmland birds, 19902000. Agriculture, Ecosystems \& Environment 116(3-4): 189-196. https://doi.org/10.1016/j.agee.2006.02.007

DövÉNYI, Z. (2010): Magyarország kistájainak katasztere. MTA Földrajztudományi Kutatóintézet, Budapest.

EgGers, S., Unell, M. \& PÄRT, T. (2011): Autumn-sowing of cereals reduces breeding bird numbers in a heterogeneous agricultural landscape. Biological Conservation 144(3): 11371144. https://doi.org/10.1016/j.biocon.2010.12.033

Ellison, K. S., Ribic, C. A., SAmple, D. W., FAwCETT, M. J., \& DAdisman, J. D. (2013): Impacts of tree rows on grassland birds and potential nest predators: a removal experiment. PloS ONE 8(4): e59151. https://doi.org/10.1371/journal.pone.0059151

ERDÖS, S., BÁldI, A. \& BATÁRY, P. (2009): Nest site selection and breeding ecology of Skylarks Alauda arvensis in Hungarian farmland. Bird Study 56(2): 259-263. https://doi.org/10.1080/00063650902791983

FARAGÓ, S. \& KALMÁR, S. (2006): A túzok védelme Magyarországon. Life Nature Project 2005. évi monitoring jelentése. Magyar Apróvad Közlemények 2006. évi különszám: 12-15.

FARAGÓ, S. (2012a): A határstruktúra alakulása. In: FARAGÓ, S. (szerk.): A LAJTA Project - Egy tartamos mezei vad és ökoszisztéma vizsgálat 20 éve. Nyugat-magyarországi Egyetem Kiadó, Sopron. 93-117.

FARAGÓ, S. (2012b): Bevezetés - A LAJTA Project. In: FARAGÓ, S. (szerk.): A LAJTA Project Egy tartamos mezei vad és ökoszisztéma vizsgálat 20 éve. Nyugat-magyarországi Egyetem Kiadó, Sopron. 7-20. 
FARAGÓ, S. (2012c): Vetésszerkezet és az élőhely-diverzitás változása. In: FARAGÓ S. (szerk.): A LAJTA PROJECT - Egy tartamos mezei vad és ökoszisztéma vizsgálat 20 éve. Nyugatmagyarországi Egyetem kiadó, Sopron. 34-65.

FARAGÓ, S. (2018): Túzok a Kisalföldön. Soproni Egyetem Kiadó. 97-108.

Faragó, S., Dittrich, G., Horváth-HANGya, K. \& WinkLer, D. (2012): Twenty years of the Grey Partridge population in the LAJTA Project (Western Hungary). Animal Biodiversity and Conservation 35(2): 311-319.

FOURNIER, E. \& LOREAU, M. (2001): Respective roles of recent hedges and forest patch remnants in the maintenance of ground-beetle (Coleoptera: Carabidae) diversity in anagricultural landscape. Landscape Ecology 16(1): 17-32. https://doi.org/10.1023/A:1008115516551

GÁL, J. \& MAROSÁN, M. (2008): Studies on the biometry, foraging- and reproductive biology of the Quail (Coturnix coturnix, Linnaeus 1758) in Hungary. Acta Agronomica Óváriensis 50(2): 43-51.

GARDNER, J. L. (1998): Experimental evidence for edge related predation in a fragmented agricultural landscape. Australian Journal of Ecology 23(4): 311-321. https://doi.org/10.1111/j.1442-9993.1998.tb00736.x

GeORge, K. (1990): Zu den Habitatansprüchen der Wachtel (Coturnix coturnix). Acta Ornithologica 2(2): 133-142.

GEORGE, K. (1996): Habitatnutzung und Bestandssituation der Wachtel Coturnix coturnix in Sachsen-Anhalt. Vogelwelt 117(4-6): 205-211.

Glutz von Blotzheim, U. N., BAuer, K. M., \& Bezzel, E. (1973): Handbuch der Vögel Mitteleuropas. AULA-Verlag GmbH, Wiesbaden. Band 5. 283-320.

Green, R. E. \& Stowe, T. (1993): The decline of the Corncrake Crex crex in Britain and Ireland in relation to habitat change. Journal of Applied Ecology 30(4): 689-695.

Green, R. E., Osborne, P. E. \& Sears, E. J. (1994): The distribution of passerine birds in hedgerows during the breeding season in relation to characteristics of the hedgerow and adjacent farmland. Journal of Applied Ecology 31(4): 677-692. https://doi.org/10.2307/2404158

Guisan, A. \& THUILler, W. (2005): Predicting species distribution: offering more than simple habitat models. Ecology Letters 8(9): 993-1009. https://doi.org/10.1111/j.1461$\underline{0248.2005 .00792 . \mathrm{X}}$

GuYOMARC'H, J. C. (2003): Elements for a common quail (Coturnix c. coturnix) management plan. Game \& Wildlife Science 20: 1-92.

Guyomarc'H, J. C., Combreau, O., Pugicerver, M., Fontoura, P., Aebischer, N. J. \& WaLlaCE, D. I. M. (1998): Coturnix coturnix Quail. BWP Update 2. 27-46.

HADARICS, T. \& ZALAI, T. (2008): Nomenclator Avium Hungariae. MME, Budapest.

Halász, G. (2006): Magyarország erdészeti tájai. Állami Erdészeti Szolgálat, Budapest.

Hall, L. S., Krausman, P. R. \& Morrison, M. L. (1997): The habitat concept and a plea for standard terminology. Wildlife Society Bulletin 25(1): 173-182.

Hammer, Ø., Harper, D. A. T. \& RYAN, P. D. (2001): PAST: Paleontological statistics software package for education and data analysis. Palaeontologia Electronica 4(1): 1-9.

Hinsley, S. A. \& Bellamy, P. E. (2000): The influence of hedge structure, management and landscape context on the value of hedgerows to birds: a review. Journal of Environmental Management 60(1): 33-49. https://doi.org/10.1006/jema.2000.0360

Holland, J., Smith, B., Birkett, T. \& Southway, S. (2012): Farmland bird invertebrate food provision in arable crops. Annals of Applied Biology 160(1): 66-75. https://doi.org/10.1111/j.1744-7348.2011.00521.x

HuhTA, E., MAPPES, T. \& JOKIMÄKI, J. (1996): Predation onartificial ground nests in relation to forest fragmentation, agricultural land and habitat structure. Ecography 19(1): 85-91. https://doi.org/10.1111/j.1600-0587.1996.tb00158.x 
HutCHESON, K. (1970): A test for comparing diversities based on the Shannon formula. Journal of Theoretical Biology 29(1): 151-154.

IBM CORP. (2011): IBM SPSS Statistics for Windows, Version 20.0. Armonk, NY: IBM Corp.

JAKUCS, P. \& PRÉCSÉNYI, I. (1981): A fitocönozisok. In: HortobÁGYI, T. \& SimON, T. (szerk.): Növényföldrajz, társulástan és ökológia. Tankönyvkiadó, Budapest. pp. 192-263.

JANZEN, F. J. \& STERN, H. S. (1998): Logistic regression for empirical studies of multivariate selection. Evolution 52(6): 1564-1571. https://doi.org/10.1111/j.1558-5646.1998.tb02237.x

Jolliffe, I. T. (2002): Principal Component Analysis. $2^{\text {nd }}$ edition, Springer-Verlag, New York. $30-42$.

KEARNEY, M. (2006): Habitat, environment and niche: what are we modelling? Oikos 115(1): 186-191. https://doi.org/10.1111/j.2006.0030-1299.14908.x

KeVE, A., ZsÁK, Z. \& KASZAB, Z. (1953): A fürj gazdasági jelentősége. Természettudományi Évkönyv 4: 197-209.

KIRÁLY, A. \& KiRÁLY, G. (2014): Gyomnövényfelvételezés a LAJTA és MOSON Project területén. Kutatási jelentés, Sopron. 3-10.

Kleijn, D., Baquero, R. A., Clough, Y., Díaz, M., Esteban, J., Fernández, F., Gabriel, D., Herzog, F., Holzschuh, A., Jöhl, R., Knop, E., Kruess, A., Marshall, E. J., Steffan-Dewenter, I., Tscharntke, T., Verhulst, J., West, T. M. \& Yela, J. L. (2006): Mixed biodiversity benefits of agri-environment schemes in five European countries. Ecology Letters 9(3): 243-254. https://doi.org/10.1111/j.1461-0248.2005.00869.x

Kosicki, J. Z., ChYlarecki, P. \& ZDUniaK, P. (2014): Factors affecting Common Quail's Coturnix coturnix occurrence in farmland of Poland: is agriculture intensity important? Ecological Research 29(1): 21-32. https://doi.org/10.1007/s11284-013-1093-2

KovÁCs, G. (2005): Fürj (Coturnix coturnix) előfordulása vízi élőhelyeken. Aquila 112: 221.

KÜLLEY, J. (1924): Telelő fürj. Aquila 30-31: 301.

LANDIS, J. \& KoCH, G. (1977): The measurement of observer agreement for categorical data. Biometrics 33(1): 159-174.

McGowan, P. J. K., De JuAna, E. \& Boesman, P. (1994): Common Quail (Coturnix coturnix). In: del Hoyo, J., Elliott, A., Sargatal, J., Christie, D. A. \& De Juana, E. (eds.): Handbook of the Birds of the World. Vol. 2: New World Vultures to Guineafowl. Lynx Edicions, Barcelona. 509.

Michailov, C. (1996): Seasonal changes in the population of the Quail (Coturnix coturnix L., 1758) in the Southwest of Bulgaria. Proceedings of the International Union of Game Biologists XXII. Congress. Sofia, Bulgaria. 14-19.

MME (2018): Magyarország madarai: Fürj. http://www.mme.hu/magyarorszagmadarai/madaradatbazis-cotcot Downloaded: 2019-10-01

MoReby, S. J. \& AEBISCHER, N. J. (1992): Invertebrate abundance on cereal fields and set-aside land: implications for wild gamebird chicks. British Crop Protection Council Monographs 50: $181-186$.

MoRELLI, F. (2013): Relative importance of marginal vegetation (shrubs, hedgerows, isolated trees) surrogate of HNV farmland for bird species distribution in Central Italy. Ecological Engineering 57: 261-266. https://doi.org/10.1016/j.ecoleng.2013.04.043

Morelli, F., SANTOLINI, R. \& SiSTI, D. (2012): Breeding habitat of red-backed shrike Lanius collurio on farmland hilly areas of Central Italy: is functional heterogeneity one important key? Ethology Ecology \& Evolution $24(2)$ : 127-139. https://doi.org/10.1080/03949370.2011.635696

MORRIS, D. W. \& DAVIDSON, D. L. (2000): Optimally foraging mice match patch use with habitat differences in fitness. Ecology 81(8): 2061-2066. https://doi.org/10.1890/00129658(2000)081[2061:OFMMPU]2.0.CO;2

MorRIS, D. W. (2003): Toward an ecological synthesis: a case for habitat selection. Oecologia 136(1): 1-13. https://doi.org/10.1007/s00442-003-1241-4 
MORRIS, D. W. (1999): Has the ghost of competition passed? Evolutionary Ecology Research 1: $3-20$.

NÉMETH, T. M. \& WinKLER, D. (2017): The impact of unmown refuge-strips on the breeding site fidelity of Common Quail (Coturnix coturnix) - a case study. Hungarian Small Game Bulletin 13: 289-296. https://doi.org/10.17243/mavk.2017.289

NÉmeth, T. M., Winkler, D. \& FARAGÓ, S. 2014. The Common Quail (Coturnix coturnix Linnaeus, 1758) population of the Lajta Project during the period of 2013-2014. Magyar Apróvad Közlemények 12: 125-134. https://doi.org/10.17243/mavk.2014.125

PANEK, M. (1997): The effect of agricultural landscape structure on food resources and survival of Grey Partridge Perdix perdix chicks in Poland. Journal of Applied Ecology 34(3): 787-792.

PANEK, M. (1998): Use of habitat by Common Quail (Coturnix coturnix) in Western Poland. Gibier Faune Sauvage 15: 407-412.

Patil, G. P. \& TAillie, C. (1982): Diversity as a concept and its measurement. Journal of the American Statistical Association 77(379): 548-561.

Paton, P. W. (1994): The effect of edge on avian nest success: How strong is the evidence? Conservation Biology 8(1): 17-26.

PerenNou, C. (2009): European Union Management Plan 2009-2011, Common Quail Coturnix coturnix, Technical report. European Commission, Luxembourg. 8-30.

Puigcerver, M., Rodriguez-Teijeiro, J. D. \& Gallego, S. (1999): The effects of rainfall on wild populations of Common Quail (Coturnix coturnix). Journal für Ornithologie 140(3): 335-340.

Puigcerver, M., Vinyoles, D. \& Rodríguez-TeiJeiro, J. D. (2007): Does restocking with Japanese quail or hybrids affect native populations of Common Quail Coturnix coturnix? Biological Conservation 136(4): 628-635. https://doi.org/10.1016/j.biocon.2007.01.007

RANDS, M. R. W. (1986): Effects of hedgerow characteristics on partridge breeding densities. Journal of Applied Ecology 23(2): 479-487. https://doi.org/10.2307/2404030

RAPOS, P. (1957): Fürj késői költése. Aquila 63-64: 276.

RÉNYI, A. (1961): On measure of entropy and information. In: NEYMAN, J. (ed.): Proceedings of the 4th Berkeley Symposium on Mathematical Statistics and Probability (Vol. I.), University of California Press. Berkley, USA. 547-561.

Robinson, R. A. \& Sutherland, W. J. (2002): Post-war changes in arable farming and biodiversity in Great Britain. Journal of Applied Ecology 39(2): 157-176. https://doi.org/10.1046/j.1365-2664.2002.00695.x

Rodríguez-Teijeiro, J. D., SArdÀ-Palomera, F., Alves, I., Bay, Y., Beça, A., Blanchy, B., Borgogne, B., Bourgeon, B., Colaço, P., Gleize, J., Guerreiro, A., Maghnouj, M., Rieutort, C., Roux, D. \& PuigCERVER, M. (2010): Monitoring and management of Common Quail Coturnix coturnix populations in their atlantic distribution area. Ardeola 57: 135-144.

RosenzWeIG, M. L. (1981): A theory of habitat selection. Ecology 62(2): 327-335. https://doi.org/10.2307/1936707

SAINT-Jalme, M. \& GuYOMARC'H, J. C. (1989): Recent changes in population dynamics of European Quail in the western part of its breeding range. In: Myrberget, S. (ed.) Transactions of the XIX ${ }^{\text {th }}$ Congress of the International Union Game Biologists. Norwegian Institute for Nature Research, Trondheim, Norway, pp. 130-135.

Sargent, R. A., Kilgo, J. C., Chapman, B. R. \& Miller, K. V. (1998): Predation of artificial nests in hardwood fragments enclosed by pine and agricultural habitats. Journal of Wildlife Management 62(4): 1438-1442.

SAS InstituTe InC. (2013): Base SAS ${ }^{\circledR} 9.4$ Procedures Guide: Statistical Procedures. Second Edition. Cary, NC, USA: SAS Institute Inc.

Schaffers, A. P., Raemakers, I. P., SÝkora, K. V. \& Ter BraAK, C. J. F. (2008): Arthropod assemblages are best predicted by plant species composition. Ecology 89(3): 782-794. https://doi.org/10.1890/07-0361.1 
SHANNON, C. E. \& WEAVER, W. (1949): The mathematical theory of communication. University Illionis Press. Urbana, (Illionis) USA.

Siemann, E., Tilman, D., HaArstad, J. \& Ritchie, M. (1998): Experimental tests of the dependence of arthropod diversity on plant diversity. The American Naturalist 152(5): 738750. https://doi.org/10.1086/286204

Stoate, C., Boatman, N. D. Borralho, R. J., Rio Carvalho, C., De Snoo, G. R. \& Eden, P. (2001): Ecological impacts of arable intensification in Europe. Journal of Environmental Management 63(4): 337-365. https://doi.org/10.1006/jema.2001.0473

SzÉP, T., NAGY, K., NAGY, Zs. \& Halmos, G. (2012): Population trends of common breeding and wintering birds in Hungary, decline of long-distance migrant and farmland birds during 1999-2012. Ornis Hungarica 20(2): 13-63. https://doi.org/10.2478/orhu-2013-0007

SzÜTS, B. (1898): Fürj januáriusban Szatmár-vármegyében. Természettudományi Közlöny 30(343): 165.

Thomas, C. F. G. \& Marshall, E. J. P. (1999): Arthropod abundance and diversity in differently vegetated margins of arable fields. Agriculture, Ecosystems \& Environment 72(2): 131-144. https://doi.org/10.1016/S0167-8809(98)00169-8

TóTHMÉRÉSZ, B. (1997): Diverzitási rendezések. Scientia Kiadó, Budapest. 57-64.

Tryjanowski, P., Hartel, T., BÁldi, A., Szymański, P., Tobolka, M., Herzon, I., GoŁawski, A., KonvičKa, M., Hromada, M., Jerzak, L., Kujawa, K., Lenda, M., OrŁowski, G., PANeK, M., Skórka, P., Sparks, T., Tworek, S., Wuczyński, A. \& ŻMihorSKi, M. (2011): Conservation of farmland birds faces different challenges in Western and Central-Eastern Europe. Acta Ornithologica 46(1): 1-12. https://doi.org/10.3161/000164511X589857

UdVARDY, M. (1941): A Hortobágy madárvilága. Tisia 5: 92-169.

ViCKERY, J. A., CARTER, N. \& FULlER, R. J. (2002): The potential value of managed cereal field margins as foraging habitats for farmland birds in the UK. Agriculture, Ecosystems \& Environment 89(1-2): 41-52. https://doi.org/10.1016/S0167-8809(01)00317-6

ViszLó, L. (2007): A természetkímélő kaszálás gyakorlata. Információs füzet, Pro-Vértes Alapítvány, Csákvár. 7-29.

Voříšek, P., Jiguet, F., van Strien, A., Škorpilová, J., Klvanová, A. \& Gregory, R. D. (2010): Trends in abundance and biomass of widespread European farmland birds: How much have we lost? BOU Proceedings-Lowland Farmland Birds III. 1-24.

WhitTAKer, R. H., Levin, S. A. \& RoOT, R. B. (1973): Niche, habitat, and ecotope. American Naturalist 107(955): 321-338.

Wilson, J. D., Morris, A. J., Arroyo, B. E., Clark, S. C. \& Bradbury, R. B. (1999): A review of the abundanceand diversity of invertebrate and plant foods of granivorous farmland birds of northern Europe in the context of agricultural intensification. Agriculture, Ecosystems \& Environment 75(1-2): 13-20. https://doi.org/10.1016/S0167-8809(99)00064-X

Wirtitsch, M., Hoi, H., Valera, F. \& Kristin, A. (2001): Habitat composition and use in the lesser grey shrike Lanius minor. Folia Zoologica 50(2): 137-150.

Wretenberg, J., Lindström, A., Svensson, S., Thierfelder, T. \& PART, T. (2006): Population trends of farmland birds in Sweden and England: similar trends but different patterns of agricultural intensification. Journal of Applied Ecology 43(6): 1110-1120. https://doi.org/10.1111/j.1365-2664.2006.01216.x 
